\title{
Training Teachers to Use Remote Sensing: The YCHANGE Project
}

Kathrin
SCHULMAN ${ }^{1}$
FHNW School of
Education,
SWITZERLAND
Josef
LAŠTOVIČKA
Charles University,
CZECHIA

\author{
Stephan FUCHS ${ }^{2}$ \\ Heidelberg University \\ of Education (formerly), \\ GERMANY
}
Nicole NOTTER ${ }^{6}$
FHNW School of
Education, (formerly)
SWITZERLAND

\author{
Martin HÄMMERLE ${ }^{3}$ \\ Heidelberg University \\ of Education (formerly), \\ GERMANY
}

\section{PremysI STYCH ${ }^{7}$ \\ Charles University, CZECHIA}

\author{
Thomas KISSER ${ }^{4}$ \\ Heidelberg University of \\ Education (formerly), \\ GERMANY
}

\section{Terje VÄLJATAGA ${ }^{8}$ \\ Tallinn University, Tallinn, ESTONIA}

\section{Alexander SIEGMUND 9}

Heidelberg University of Education, Heidelberg, GERMANY

\begin{abstract}
${ }^{1}$ Corresponding author: Dr. Kathrin Schulman, University of Applied Sciences and Arts Northwestern Switzerland (FHNW), School of Education, ISEK, Bahnhofstrasse 6, 5210 Windisch, SWITZERLAND, kathrin.schulman[at]fhnw.ch, ORCID: 0000-0002-4640-3417

${ }^{2}$ Dr., University of Bamberg, Institute of Geography, GERMANY, geografox[at]marxram.de, ORCID: 0000-0002-9156-8157

${ }^{3}$ Dr., Federal Waterways Engineering and Research Institute, Kußmaulstraße 17, 76187 Karlsruhe, GERMANY, martin. hammerle[at]alumni.uni-heidelberg.de, ORCID: 0000-0001$7527-8515$

${ }^{4}$ Dr., Landesinstitut für Lehrerbildung und Schulentwicklung, Felix-Dahn-Straße 3, 20357 Hamburg, GERMANY, t.kisser.gwgg[at]gmail.com, ORCID: ORCID: 0000-0001-5862-1377 ${ }^{5}$ Dr., Charles University, Faculty of Science, Department of applied geoinformatics and cartography, Albertov 6, Prague 128 43, CZECHIA, josef.lastovicka[at]natur.cuni.cz, ORCID: 0000-0002-0307-9688

${ }_{6}^{6}$ formerly University of Applied Sciences and Arts Northwestern Switzerland (FHNW), School of Education, ISEK, Hofackerstrasse 30,4132 Muttenz, SWITZERLAND, :

nicole.notter[at]nksa.ch, ORCID: 0000-0002-2851-499X

${ }^{7}$ Assoc. Prof. Dr., Charles University, Faculty of Science, Department of applied geoinformatics and cartography, Albertov 6, Prague 128 43, CZECHIA, stych[at]natur.cuni.cz ORCID: 0000-0002-0307-9688

${ }^{8}$ Dr., Tallinn University, School of Educational Sciences, Talinn, ESTONIA, terje.valjataga[at]tlu.ee, ORCID: 0000-0001-8109-0674

${ }^{9}$ Prof. Dr., Heidelberg University of Education and Heidelberg University, 22/10-12, Heidelberg, GERMANY, siegmund[at]ph-heidelberg.de, ORCID: 0000-0002-2904-4651
\end{abstract}

\section{Abstract}

Many people use satellite images in their professional and everyday lives, and school curricula often require their use. Yet, the ways teachers actually use satellite images in the classroom is often limited, if they use them at all. The YCHANGE project trained teachers to use remote sensing data by themselves and to use it in their classrooms. The project partners created a remote sensing curriculum which suggests how teachers can develop their students' skills in this area of geography. This curriculum is based on existing research and school curricula. The project partners created and published sample learning units, and the project webpage also offered the possibility for teachers to publish studentcreated projects. YCHANGE training event participants in Switzerland and Germany filled out an online survey. Most participants said they improved their ability to read satellite images and use them in the classroom. However, participants' evaluation of the YCHANGE materials and training events was mixed. The study shows some differences among the Swiss language regions, and significant differences between Germany and Switzerland. For example, our training events introduced the participants to the web application BLIF. On average, the German participants liked BLIF, but the participants in Switzerland rated BLIF significantly worse. We therefore recommend that future research compare remote sensing, as well as other areas of geography education, among different countries and language regions.

\section{Keywords}

Remote Sensing, Satellite Images, Teacher Training, Secondary School Teachers 
In the age of Big Data, people in many areas use satellite images and geographic information systems (GIS) (Dziob, Krupiński, Woźniak, \& Gabryszewski, 2020). They are often available to anyone with a computer or a smartphone for free (e.g., Steiniger \& Bocher, 2009; Wulder, Masek, Cohen, Loveland, \& Woodcock, 2012). A family can use Google Earth and Google Maps to plan a day trip. A youth group can take part in a citizen science project using ArcGIS online. Professionals can use them to create a flood response plan with the help of QGIS. These are just three examples of the manifold ways in which people use satellite images and GIS. Besides free options such as Google Earth and QGIS, there are many paid options for obtaining and using remote sensing data and GIS. "The global market for remote sensing is expected to increase from $\$ 11.3$ billion in 2018 to $\$ 18.9$ billion in 2023 [...]" (Sullivan, 2018). Moreover, the "2020 European Association of Remote Sensing Companies (EARSC) Industry Survey" showed that "average annual employment growth rates [...were] approximately 6\% from 2012 to 2018 and $17 \%$ in 2019 . However, $80 \%$ of employers who took part in the survey noted difficulty finding and hiring candidates" (Dziob et al., 2020, p. 1).

\section{Background}

\section{Use of Satellite Images in School}

Use of satellite images in school is far from universal (Ditter et al., 2015; Wolf, Fuchsgruber, Viehrig, Naumann, \& Siegmund, 2015). In one German study, for example, $29 \%$ of the surveyed 10 th grade students had "never worked with satellite images in the school context" (Wabnitz, 2019, p. 59, translated). In another German study, $40.5 \%$ of 10 th grade students had not yet used satellite images in school at all, while $22.8 \%$ had used satellite images for less than once per year (Kollar, 2012). Yet, some teenagers might not even realize that they are using satellite images. In the same study, only $6.3 \%$ of responding 10 th grade students said that they had never used digital globes at all and $12.8 \%$ said they had used digital globes but for only less than once per year (Kollar, 2012). If they used digital globes, then most likely they used satellite imagery, because a salient feature of a digital globe such as Google Earth is its satellite image base layer. In another German study, $66.2 \%$ of teachers and $53.5 \%$ of students said they had worked with satellite images in class (Alexandra Siegmund, 2011). In an earlier German study, $13.6 \%$ of teachers said they had never used satellite or aerial images, and $75 \%$ had used satellite or aerial images but only rarely (Klein, 2007). In that study, Google Earth was much less used. In that study, fully $70.6 \%$ of surveyed teachers had never used Google Earth, and 29.4\% used Google Earth only rarely (Klein, 2007). There are also differences between countries. For example, over $80 \%$ of students in the United Kingdom (UK) but less than $40 \%$ of students in South Korea said they had already worked with satellite images (Alexandra Siegmund, 2011). However, every student should have the chance to learn to 'read' satellite images.

Even when teachers do use satellite images in school, how they use them is often limited. In a German study (Alexandra Siegmund, 2011), teachers said they mainly use satellite images on an overhead projector transparency sheet $(55.4 \%)$, in a textbook $(43 \%)$, on the internet $(32 \%)$, as part of a computer presentation $(31 \%)$, in a newspaper $(11 \%)$ or with a learning software $(7.7 \%)$ 
(more than one choice possible). From another German study, $49 \%$ of 10 th grade students had used analogue satellite images ("e.g., in textbooks, as printout or on the overhead projector"), $24 \%$ had used satellite images as part of "films, presentations, or animations", $21 \%$ had looked at satellite images on the computer, and only $6 \%$ had worked with satellite images on the computer themselves (Kollar, 2012, p. 98, translated).

\section{Curricular Relevance}

Curricular relevance is an important condition for a more universal use of satellite images to occur in schools. Use of satellite images is already required by many curricula for secondary schools, both in Europe and beyond (e.g., Ditter et al., 2015; EDK, 2016; MKJSBW, 2018; Alexandra Siegmund, 2011).

Even when satellite images or digital globes are not explicitly mandated by a curriculum, teachers can often justify their use by linking them to other parts of the curriculum, such as general media skills (Ditter et al., 2015) or an independent enquiry study (Cheung, Pang, Lin, \& Lee, 2011). Moreover, in some cases, such as in Estonia, satellite images are part of elective programs (RÕK, 2011). Science centers and hobby courses like a space robotics program often use such elective programs to design their curricula (e.g., Tallinna Nõmme Noortemaja Kosmoseklubi, n.d.; Tartu Observatory, 2018).

\section{Students' Interest in Satellite Images}

In general, students' interest is an important influence on their learning outcomes (e.g., Guo, Klein, \& Ro, 2019; Picton, Nelson, \& Kahu, 2017), which means that student interest is relevant to teachers. Moreover, a study asked teacher students in Switzerland how they choose spatial examples. Among the top three criteria reported were: "that the pupils find interesting" and "that I personally find interesting" (Viehrig, 2017, Fig. 3).

In German studies, students had a medium to high interest in satellite images (Ditter et al., 2015; Klein, 2007; Lindner, Müller, Hodam, et al., 2019; Alexandra Siegmund, 2011). In Germany, South Korea, and the United States of America (USA), boys were significantly more interested in satellite images than girls (Klein, 2007; Alexandra Siegmund, 2011). However, some of the larger studies measuring geographic interests didn't include satellite images (e.g., Hemmer \& Hemmer, 2010; Lorenz et al., 2016), so more data would be useful for drawing conclusions about students' and teachers' interest in satellite images compared to other media.

Working with satellite images can improve students' motivation and selfconcept. In a German study (Ditter \& Siegmund, 2016), 11- to 18-year-old students participated in a four-hour workshop. Students significantly increased their perceived self-determination. This was especially true for the females. Female students, who started out with low self-determination, improved significantly after working with satellite images in the workshop. Male students had a significantly higher self-concept than female students with regard to dealing with computers and with satellite image in both pre-test and post-test. Overall, students' self-concept in dealing with satellite images improved significantly from pre- to post-test, driven largely by the improvement of female students. 


\section{The Learning Material Jungle}

Like in the area of GIS (Alexander Siegmund, Volz, \& Viehrig, 2007), teachers are confronted with a jungle of research, opinions and learning materials dealing with satellite images. These include, by way of example:

- Satellite images printed in school books;

- ESA's school atlas kit (https://earth.esa.int/web/guest/-/esa-school-atlas)

- Google Earth;

- Aerial and satellite imagery layers in GIS viewers such as https://map.geo.admin.ch/, satellite imagery sites such as USGS's Earth Explorer (https://earthexplorer.usgs.gov/) as well as satellite images published on a variety of internet sites (see e.g. Kholoshyn, Bondarenko, Hanchuk, \& Varfolomyeyeva, 2020, for more examples) and in print media;

- Specialized learning platforms such as

1. FIS: https://www.fis.uni-bonn.de/ (see also Lindner, Müller, Hodam, et al., 2019; Lindner, Müller, Ortwein, et al., 2019; Rienow et al., 2018)

2. Geospektiv: https://www.geospektiv.de/ (see also Dannwolf, Matusch, Keller, Redlich, \& Siegmund, 2020; Wolf et al., 2015)

3. Glokal Change: https://www.glokalchange.de/ (see also Ditter et al., 2015; Jahn, Haspel, \& Siegmund, 2011)

4. SEOS: https://seos-project.eu/ (see also Reuter, 2012)

5. Sentinel Hub: https://www.sentinel-hub.com/explore/education/ (see also Asimakopoulou, Nastos, \& Vassilakis, 2019);

- Smartphone apps (see Lindner, Müller, Ortwein, et al., 2019; Rienow et al., 2018);

- Tools that enable students to understand more about satellite images by manipulating them (e.g., classifying, selecting bands) such as BLIF (https://server2.blif.de) (see also Ditter et al., 2015); and

- Other published learning materials.

Generally, teachers need to exert considerable effort and time to select learning materials for their students. An Austrian study found this can impede teachers' integration of the topic of climate change into their teaching (Radl, 2018). Therefore, it is reasonable to consider that this effort of selecting suitable learning materials could also impede integrating satellite images into the classroom.

Schools' infrastructure often can impede the integration of digital satellite images into class. Lindner, Müller, Ortwein, et al. (2019) argue that "E-learning is indispensable for working with satellite images" (p. 246, translated). At the same time, they are concerned that "[t]he infrastructure of many schools is [...] inadequate. Many classes have to share the use of few computer (rooms), the computers themselves are often outdated and the internet, when it works, is slow (INITIATIVE D21 2016)" (p. 245, translated).

Another problem is that most learning materials and applications are only available in a limited number of languages. For instance, Amici and Tesar (2020) conducted a project with 17- to 18-year-old students in Italy. The students used ESA's SNAP software alone (cohort 1), SNAP and Google Earth (cohort 2) or WebGIS and Google Earth (cohort 3). They note that "English language 
proficiency was a challenge for the first cohort when trying to make sense of specific terminology" (p. 9). For cohorts 2 and 3, they recruited only students who were good in English. Students also used a "glossary and [...] Google Translator" (p. 9).

Additionally, teacher expertise is a factor impeding the integration of satellite images into classroom teaching. In Alexandra Siegmund's study (2011, p. 87, translated) only $50.8 \%$ of the surveyed teachers in Germany stated that they had "received a technical [fachliche], methodological and/or didaktical introduction to working with satellite images"1.

\section{Existing Research Base}

"In the last 15 years or more, there has been a significant shift towards what has been called "evidence-based education" [...]" (Simpson, 2019, p. 1). There is a narrow research base regarding students dealing with satellite images and the evaluation of certain learning materials. There are even fewer studies of teachers dealing with satellite images.

Learning with satellite images is not easy for all students. In a German study (Klein, 2007), 4.9\% of students said they did not understand the content at all when working with satellite images and $9.5 \%$ of students understood the content only poorly. This was the third worst result of all media included in the study. There was no significant difference between different grade bands. In another German study (Gehring, 2016), only 33.3\% of students in one group and $22.2 \%$ in a second group somewhat agreed or agreed that "working with satellite images [was] very easy" (p. 143, translated). A different study showed that the number of students who thought working with satellite images was hard varied by country, ranging from less than $20 \%$ to 60\% (Alexandra Siegmund, 2011).

Easy or not, satellite images can help students to better understand the world around them. In a study of elementary students participating in an Earth Observation Day activity in the USA, focusing on a local heat island effect, $96.3 \%$ agreed or strongly agreed that "[t]he activity helped [...them] better understand [...their] local environment" (Adaktylou, 2020, p. 524). In a study in Poland, many teachers "stressed the substantial benefit from working on real data that students could obtain by themselves", i.e., from their own neighborhoods (Dziob et al., 2020, p. 7).

Even if students use satellite images more often, they do not automatically get better at reading them. Kollar (2012) developed an empirically tested competency model for reading satellite images. In her study, there was no significant difference in understanding satellite images between three groups of students: those who never or rarely used satellite images, those who used them sometimes, and those who used them frequently (Kollar, 2012). There was, however, a significant difference between the three groups in evaluating the potentials and limits of satellite images. Kollar's study also showed that false color

${ }^{1}$ This refers to the central European understanding of the term. It is spelled didactical with a ' $k$ ' to differentiate it from the general English meaning of the word didactical based on a suggestion made by Clare Brooks during her IGU-CGE Singapore presentation (2016) (see also Viehrig et al., 2019). 
images are harder to read than true color images. Even harder is comparing two or more images.

Students and experts read satellite images differently. Wabnitz (2019) compared $10^{\text {th }}$ grade students versus experts with the help of eye-tracking. She observed that students and experts tend to focus on different elements of the images. For example, students "focus[ed] on visually salient image elements such as individual trees or mountain peaks" which weren't relevant for interpreting the image (ibid., p. 103, translated). Whereas experts focused on elements which were relevant for interpreting the image, such as the outer areas, a plantation, or a border zone. Moreover, experts more frequently connected what they saw on the satellite image to their previous knowledge. They used that to "establish connections between image elements" (ibid, p. 101, translated). Yet, at least one of the students couldn't identify paths in a forest even after having identified the forest area. In contrast to students, experts often "look[ed] for elements that could in principle fit into their mental model" (ibid., p. 109, translated).

Results regarding gender differences are mixed. In Klein's (2007) study, boys in Germany reported a significantly better understanding of content when using satellite images than girls. In Alexandra Siegmund's (2011, p. 97) study, there were no significant differences between boys and girls in Germany regarding how "hard to understand" (translated) they thought satellite images are. However, in Poland and the USA, girls agreed significantly more frequently than boys that satellite images are "hard to understand" (ibid.). In Kollar's German study (2012), controlling for previous experience with satellite images, boys understood satellite images significantly better than girls, but there was no significant difference between boys' and girls' ability to evaluate satellite images.

Existing platforms for learning how to use remote sensing have mixed reviews. Students in Germany studied by Dannwolf et al. (2020) evaluated modules from the Geospektiv learning platform, which uses BLIF, rather positively. On average, those students evaluated the "Rainforest in Danger" module as fairly interesting and the tasks as neither too demanding nor too easy (Dannwolf et al., 2020). They also liked the layout and thought the navigation was easy. The students, on average, agreed that the videos/animations, and "graphics helped [them] to better understand the content" (ibid., p. 9). Correlation analysis for three learning modules showed that 'design' and students' 'interest/enjoyment' were "important to achieve higher 'perceived competence' [...] and 'perceived choice' [...]" (ibid., p. 11). In line with the results of Dannwolf et al. (2020), the majority of students evaluating another German learning platform, FIS, agreed or strongly agreed that "[t]he illustrations and animations are helpful for completing the tasks" (Hodam, Rienow, \& Jürgens, 2020, p. 12). The students' views of the helpfulness of such illustrations and animations varied by FIS learning module. In another German study, Lindner, Müller, Hodam, et al. (2019) evaluated an elective course for Grades 8 and 9 which used the learning platform FIS, the ISS/CE portal and SNAP. Only $4.2 \%$ of students thought that satellite images were not helpful for "understand[ing] the topics" studied (p. 159).

On the other hand, Gehring (2016) evaluated two versions of the Geospektiv volcano module, and found that $50 \%$ (version 1) and $22.2 \%$ (version 2) of students disagreed or somewhat disagreed that "[t]he learning module was self- 
explanatory" (p. 130, translated). In the study by Hodam et al. (2020), 24.2\% of students thought that "[t]he FIS learning materials are too difficult", and $15.5 \%$ were undecided, which, although a minority, still totals $39.7 \%$ of students (ibid., p. 11). This shows that there is a need to find perhaps a more relatable approach to help this significant number of students with understanding remote sensing.

Experiencing satellite images in school can even impact a students' future job choice. In a study in Poland, $61.5 \%$ of high school teachers thought that whether "such projects could influence students' future careers and directions of study" "depend[s] on the class and the subjects in which they sought to advance" (Dziob et al., 2020, p. 8). One teacher was quoted as suggesting that students "“" [...] usually think about studying in [a] run of the mill way: they know only a few of the most popular fields. Any activity like this shows them something new and can inspire at least some of them. [...]"'” (ibid., p. 8).

In geography education in general, there are some international comparison studies (see e.g. overview in Alexandra Siegmund \& Viehrig, 2012), and there is an international study group which seeks to establish geography as a subject for an international assessment similar to the TIMSS studies (Solem et al., 2018). However, studies which compare countries or different regions within one country are clearly in the minority. With regard to satellite images, Alexandra Siegmund (2011) compared Germany, Poland, England, South Korea and the USA. However, although the web-based application BLIF is available in several languages, we could find no prior international comparative studies evaluating it or its use.

\section{Applying research to the classroom}

It is self-evident that in order to teach in an evidence-based way, teachers need to be able to access research evidence. Such academic research is not very accessible to teachers (see e.g., discussions in Avci et al., 2021; Billo et al., 2019; and Viehrig et al., 2019). Research is often published in English. On the one hand, that makes research accessible to people in many countries. On the other hand, teachers and teacher students in non-English-speaking countries sometimes have only limited English skills (Viehrig et al., 2019). Translation apps such as DEEPL and electronic dictionaries can help these teachers to understand research publications. However, they do not completely solve the problem, because terms can have different conceptual connotations in different societies and even within one society between different stakeholder groups, something with which teachers are often unfamiliar (Viehrig et al., 2019). Other constraints, such as lack of time, also limit access to research (see e.g., Avci et al., 2021; Billo et al., 2019).

Additionally, Plavén-Sigray, Matheson, Schiffler, and Thompson (2017) show that authors of academic articles often fail to write in an easily comprehensible way. The readability of academic papers has decreased considerably and steadily over time. In 2015 , more than $20 \%$ of the articles they studied had a reading level score beyond college graduate.

To teach in an evidence-based way, teachers also need to translate research evidence into practice. Teachers, however, often have difficulties with translating research into their classroom practice (see e.g., discussions in Avci et al., 2021; 
and Billo et al., 2019). Often, projects dealing with satellite images in education deal only with development of a learning product (e.g., "Glokal Change" and "SEOS"), without making it explicit whether or how the product builds on educational research evidence. Other projects deal with pure research (e.g., Kollar, 2012, Wabnitz, 2019), leaving it to the teachers to translate the research into learning materials. Projects that explain and translate fundamental educational research results into outputs teachers can use directly in practice are rare.

\section{The "YCHANGE" project}

YCHANGE is short for "Young Scientists as Change Explorers - Students Evaluating Environmental Change in Europe with Digital Space Technologies". In this two-year project, researchers from Tallinn University (Estonia), Charles University Prague (Czechia), Heidelberg University of Education (Germany) and the FHNW School of Education (Switzerland) worked together. The German researchers were responsible for the overall project management. Each university's team was responsible for its own part of the project (e.g., training events) and contributed to the success of the overall project.

\section{Project Aims}

YCHANGE contributed to the research base of remote sensing education. The project also contributed to translating research into practical learning materials. YCHANGE aimed to improve teachers' and students' competence in dealing with satellite images. The project also wanted to make teachers and students more aware of jobs that use remote sensing. YCHANGE also aimed to help students to use satellite images to learn about human-environment interactions and environmental change.

\section{Web Platform}

The homepage for the project is https://ychange.rgeo.de/. The Estonian researchers led development of the web platform, which runs on Elgg. The platform is an online space that includes all YCHANGE materials, as well as news and links. It makes the materials available to teachers, teacher educators, students, and anyone else who is interested. After registration, teachers can create groups and invite their students to join. Different group activities - such as blogs, forums, pages, feeds, and files - are possible.

\section{BLIF}

Researchers from Heidelberg University of Education developed BLIF to enable students and teachers to work with satellite images themselves (e.g., Ditter et al., 2015; Viehrig et al., 2018). The learning platform Geospektiv integrates BLIF (e.g., Dannwolf et al., 2020; Wolf et al., 2015). BLIF has been a part of courses for teachers, trainee teachers, students, and others at Heidelberg's GIS station. Between 2010 and 2019, GIS station staff taught over 200 courses in the area of earth observation (Dannwolf et al., 2020). When the Landsat format changed, the Heidelberg team needed to update BLIF. This led to some delays in the YCHANGE project. The YCHANGE project made the BLIF user interface available in more languages. As of February 2021, BLIF is available in German, English, Spanish, Italian and French. 


\section{Remote Sensing Curriculum}

The YCHANGE researchers created a remote sensing curriculum. The appendix of this paper is a slightly updated version of it. The curriculum applies research (Kollar, 2012) and takes into account curricula from the partner countries (e.g., AKSA, 2013; CD Genève 2016; CIIP, 2008; EDK, 1994, 2016; EDM Lausanne, 2016; FG Bäumlihof, 2014; Jeřábek, Krčková, \& Hučínová, 2007; KS Küsnacht, 2016; KS Limmattal, 2013/14; KS Olten, 2014; KS Zürcher Unterland, 2011/12; Ld Lugano, 2008; NKSA, 2013; RÕK, 2011).

The remote sensing curriculum is a guide for teachers. It gives them an ordered overview about which activities using satellite images are possible in which order. It also helps teachers to create differentiated tasks.

The curriculum was color-coded based on our experiences with teacher training events. The colors highlight what students can do with different tools (printouts, Google Earth, and BLIF).

\section{Student Projects and Web Map}

The Czech researchers led the development of the web map. It uses ESRI's ArcGIS Online platform.

The YCHANGE researchers developed a template for uploading student projects to the web platform. This provided a common structure, making it easier to understand the students' work, but still gave teachers freedom for doing projects with their students. Students could upload their work to the web platform, for instance after examining their local area with the help of satellite images, and teachers could review students' work before making it publicly visible on the platform.

The web map shows the location of sample projects and would also show published student projects. However, no student actually chose to publish a project before the end of YCHANGE.

\section{The Sample Projects}

The YCHANGE researchers created sample projects (Table 1), covering a wide range of topics. Teachers can download the sample projects and use the included worksheets with their students. Many of the worksheets adhere to a common template. 
Table 1

Overview of Sample Projects Created for YCHANGE

\begin{tabular}{|c|c|c|}
\hline Partner & Title & Languages \\
\hline Czechia & $\begin{array}{l}\text { Disturbance of forest ecosystems in the high } \\
\text { Tatras }\end{array}$ & English, Czech \\
\hline Czechia & $\begin{array}{l}\text { The use of agricultural land in the vicinity of } \\
\text { the Prague agglomeration }\end{array}$ & English, Czech \\
\hline Czechia & $\begin{array}{l}\text { Observation of forest changes in the Jizera } \\
\text { Mountains }\end{array}$ & English, Czech \\
\hline Germany & Greenhouse farming in Almería (Spain) & English, German \\
\hline Germany ${ }^{\circ}$ & Living on the edge of a volcano & English, Estonian, German \\
\hline Germany & Lignite mining in the Rhineland (Germany) & English, German \\
\hline Switzerland $^{\circ}$ & Flooding in Switzerland & English, Estonian, German \\
\hline Switzerland & Natural resources: the stone pit Jakobsberg & English, German \\
\hline Switzerland & Urban sprawl in Basel & English, German \\
\hline Switzerland & The Aletsch glacier* & $\begin{array}{l}\text { English, German, Italian, } \\
\text { French }\end{array}$ \\
\hline
\end{tabular}

* This project uses a different format than the other examples

- Estonian translation by the Estonian partner

The Swiss researchers created one sample project ("The Aletsch glacier") in a different format than the others to better fit their national situation. "The Aletsch glacier" materials offer many of the tasks in different versions (printout, Google Earth, and BLIF). The materials use more visualizations, e.g., descriptions with screenshots instead of just a written description for the step-by-step BLIF tasks. The materials also explicitly link to the remote sensing curriculum. A teacher's guide is part of the materials. It includes for example comments on differentiation.

\section{Training events}

As part of the project, the researchers conducted training events for teachers (Table 2).

Teachers were less interested than anticipated to participate in a training event and the accompanying research. The Estonian researchers couldn't conduct a single training event due to a lack of willing participants. In Germany and Switzerland, there were fewer participants than anticipated. In Czechia, 261 teachers participated in the training events, but there is no research data. Research data is also unavailable from some of the German teacher training events. 
Table 2

Overview of Dedicated Training Events for Teachers

\begin{tabular}{lllll}
\hline Partner & Place/year & Data collected & Language & Duration \\
\hline Switzerland & Lisbon/2017 & yes & English & $1 \mathrm{~h}$ \\
Switzerland & Windisch/2018 & yes & German & $2.5 \mathrm{~h}$ \\
Switzerland & Lausanne/2018 & yes & French & $2 \mathrm{~h}$ \\
Switzerland & Locarno/2018 & yes & English & $2.4 \mathrm{~h}$ \\
Czechia & Prague/2017 & no & Czech & $3 \mathrm{~h}$ \\
Czechia & Prague/2017 & no & Czech & $3 \mathrm{~h}$ \\
Czechia & Prague/2017 & no & Czech & $3 \mathrm{~h}$ \\
Czechia & Krkonose/2017 & no & Czech & $3 \mathrm{~d}$ \\
Czechia & Prague/2018 & no & Czech & $3 \mathrm{~h}$ \\
Czechia & Prague/2018 & no & Czech & $3 \mathrm{~h}$ \\
Czechia & Prague/2018 & no & Czech & $3 \mathrm{~h}$ \\
Czechia & Krkonose/2018 & no & Czech & $5 \mathrm{~d}$ \\
Czechia & Otrokovice/2018 & no & Czech & $6 \mathrm{~h}$ \\
Czechia & Pardubice/2018 & no & Czech & $6 \mathrm{~h}$ \\
Czechia & Prague/2018 & no & Czech & $3 \mathrm{~d}$ \\
Germany & Tübingen/2017 & no & German & $1.25 \mathrm{~h}$ \\
Germany & Heidelberg/2017 & no & German & $3 \mathrm{~h}$ \\
Germany & Dillingen/2018 & no & German & $1.25 \mathrm{~h}$ \\
Germany & Heidelberg/2018 & yes & German & $4 \mathrm{~h}$ \\
\hline & & & no & no
\end{tabular}

In their training events, the German researchers introduced the YCHANGE project, its web platform, and its sample projects within the context of remote sensing in school education. They partly went beyond the YCHANGE sample projects and beyond Europe as a spatial example in their hands-one remote sensing tasks during the training events. They used novel examples such as plantations in Costa Rica. While these materials also used BLIF and had a similar structure and tasks to those of the included YCHANGE materials, they were not part of the YCHANGE sample projects.

YCHANGE researchers also included the project into teacher training courses at the partner universities. Additionally, the lead author also included the project as a small part of some training events on the new Swiss 'Curriculum 21'.

\section{Research Questions and Methods}

The project was set up to use educational design research (EDR), which fit the aims of the project. In EDR, researchers go through cycles of testing and data collection, with further development of the materials in between. At the end, researchers derive design principles from the process (e.g., Educause, 2012; Plomp \& Nieveen, 2010). Researchers can and did use informal feedback and 
experiences from teacher trainings to improve the materials. Yet, EDR calls for systematic data to evaluate and improve outputs. Due to the projects' challenges, we couldn't complete as many cycles of data collection as planned.

\section{Research Questions}

Many existing studies focus on students' understanding and competence or on the evaluation of a specific learning environment (e.g., Adaktylou, 2020; Amici \& Tesar, 2020; Dannwolf et al., 2020; Hodam et al., 2020; Kollar, 2012; Lindner, Müller, Hodam, et al., 2019; Wabnitz, 2019), but not teachers' competence. Usage surveys show that satellite image and digital globe use differs by country and within a country by study (Klein, 2007; Kollar, 2012; Alexandra Siegmund, 2011; Wabnitz, 2019). Yet there are hardly any comparative studies. Consequently, this paper explores the following research questions:

- What are teachers' self-reported competences before the training event? Are there differences between participants in different countries? Are there differences between participants in different language regions within Switzerland?

- Does attending the training event improve teachers' self-reported competences?

- How do teachers see the curriculum, the sample projects, student projects, web platform, BLIF, and training event? Are there differences between participants in different countries? Are there differences between participants in different language regions within Switzerland?

\section{Data Collection}

In the YCHANGE project, there are two sources of data:

- Usage statistics: number of registered users of the web-platform and number of published student projects; and

- Questionnaire for teachers participating in some dedicated training events.

The survey for teachers was done online (Unipark, Switzerland). Its questionnaire was available in English, German, Estonian and Czech. Data from Unipark was exported to and analyzed in SPSS 26. Effect sizes were calculated with the help of https://memory.psych.mun.ca/models/stats/effect_size.shtml .

Few variables were normally distributed, according to analyses of One Sample Kolmogorov-Smirnov tests. Thus, in most cases non-parametric tests had to be used. Whether differences between two independent groups are statistically significant was assessed with Mann-Whitney tests. Statistical significance of differences among three independent groups was assessed with Kruskal-Wallis tests. Statistical significance of differences between two paired groups was assessed with Wilcoxon tests. For normally distributed variables, usually t-tests and ANOVAs were used. The test used is indicated, where relevant, in parentheses in the Findings section.

Data was not collected at all of the dedicated training events (Table 2). When the questionnaire was included, it was usually filled out at the end of the event before participants left. In some cases (e.g., Lausanne) the participants were given access to the questionnaire only after the training event. Administering the 
survey at non-dedicated training events was not possible due to time constraints. The researchers developed the questionnaire together. It included: background variables (age group, gender, and red-green color-blindness); self-reported competence before and after the training event; and evaluations of curriculum, sample projects, student projects, web-platform, BLIF, and the training event.

\section{Sample}

Table 3

Overview of the sample

\begin{tabular}{|c|c|c|c|c|}
\hline Training event & $n$ & Age & Gender & Questionnaire version \\
\hline Windisch 2018 & 9 & $\begin{array}{l}31-40: 44.4 \% \\
41-50: 33.3 \% \\
51-60: 22.2 \%\end{array}$ & $\begin{array}{l}66.7 \% \text { male } \\
33.3 \% \text { female }\end{array}$ & German \\
\hline Lausanne 2018 & 19 & $\begin{array}{l}18-24: 15.8 \% \\
25-30: 52.6 \% \\
31-40: 21.1 \% \\
41-50: 10.5 \%\end{array}$ & $\begin{array}{l}68.4 \% \text { male } \\
31.6 \% \text { female }\end{array}$ & German, English \\
\hline Locarno 2018 & 6 & $\begin{array}{l}25-30: 66.7 \% \\
31-40: 16.7 \% \\
51-60: 16.7 \%\end{array}$ & $100 \%$ male & German, English \\
\hline $\begin{array}{l}\text { Heidelberg } \\
2018\end{array}$ & 9 & $\begin{array}{l}18-24: 33.3 \% \\
25-30: 55.6 \% \\
\text { missing: } 11.1 \%\end{array}$ & $\begin{array}{l}11.1 \% \text { male } \\
88.9 \% \text { female }\end{array}$ & German \\
\hline
\end{tabular}

The sample consists of participants in the dedicated YCHANGE training events who submitted the online survey questionnaire. The sample only includes individuals who consented to the scientific use of their data and who responded to at least one of the content questions. Because training events with a sample size $<5$ can hardly be analyzed to any degree of statistical significance, we excluded the Lisbon training event. Table 3 shows basic information about the sample $(n=43)$.

In Switzerland, a co-author taught the training events in Lausanne and Windisch, and the lead author taught the training event in Locarno. The Swiss partners tried to recruit participants for these training events for example through their personal contacts, the VGD newsletter, a poster presentation during the VGD anniversary conference in 2018, announcements on the YCHANGE and FHNW webpages, the weblog www.gesellschaftswissenschaften-phfhnw.ch, an article in the journal GeoAgenda (Viehrig et al., 2018), and contacts with multipliers, especially teacher educators who participated together with their students.

Red-green color-blindness makes reading satellite images difficult. Worldwide, prevalence of red-green color-blindness differs by ethnicity. About $8 \%$ of male and $0.4 \%$ of female European Caucasians are red-green color blind (Birch, 2012). Our questionnaire included a color-blindness testing image. Perceiving the numeral 47 or both 47 and 17 is the normal response for someone without color-blindness. $5(26.3 \%)$ of the Lausanne participants saw only the numeral 17 , as did $1(11.1 \%)$ in Windisch, $3(33.3 \%)$ in Heidelberg, and $3(50 \%)$ in Locarno. $1(16.7 \%)$ in Locarno saw the numeral 11. All the other participants had a normal response. Thus, although all respondents recognized at least some number, many participants had a weakness in red-green color perception. 
One teacher participated in the training event both in Windisch and in Locarno. Since the survey was done anonymously, a possible double entry of that teacher cannot be excluded.

\section{Findings}

\section{What Are Teachers' Self-Reported Competences Before The Training Event? Are There Differences Between Participants In Different Countries? Are There Differences Between Participants In Different Language Regions Within Switzerland?}

Respondents had to rate their own remote sensing competence ("[...] I think I was on level ... of remote sensing competence (based on the remote sensing curriculum") on a scale ranging from 1 (corresponding to "below level 1" of the curriculum) to 7 (corresponding to "beyond level 5" of the curriculum). They also had to score themselves in four specific competency areas (dealing with remote sensing and analyzing environmental changes) both before and after the training event on a scale ranging from 1 ("I didn't know anything") to 6 ("I was already an expert"). This was a self-evaluation ("How competent did you feel before (after) this training event?"), not a test of their competence. The participants completed both sets of self-evaluation only after the training event. Thus, this is not a classic pre-post-test.

Competence with regard to satellite images. Participants' average competency level on the "YCHANGE Remote Sensing Curriculum" scale before the training event was rather low. Participants, on average, said they were between level 1 and slightly over 2 (Table 4). Participants' competence varied considerably, from below level 1 (all locations) to level 5 (Windisch) or level 4 (other locations). Overall, $16.7 \%$ said they were below level 1,35.7\% at level 1 , $26.2 \%$ at level $2,7.1 \%$ at level $3,11.9 \%$ at level 4 and only $2.4 \%$ at level $5(n=42$, see Figure 1). There were no significant differences between the Swiss language regions (Kruskal-Wallis) or between Germany and Switzerland (Mann-Whitney).

The range of participants' responses to the other three remote sensing items included in the survey varied by item and location (Table 4). However, there were no significant differences between the Swiss language regions (Kruskal-Wallis) or between Switzerland and Germany (Mann-Whitney).

Participants' average awareness of jobs that use remote sensing was in the low to medium range (Table 4). Similarly, participants rated their ability to work with satellite images by themselves as low to medium. The highest self-evaluation score for this competency was chosen by only one person in Locarno. Excluding Locarno, participants rated their ability to use satellite images in class on average somewhat lower than their ability to use them by themselves. But the difference between these two competencies was statistically insignificant, whether in Switzerland, Germany or the sample overall (Wilcoxon). 


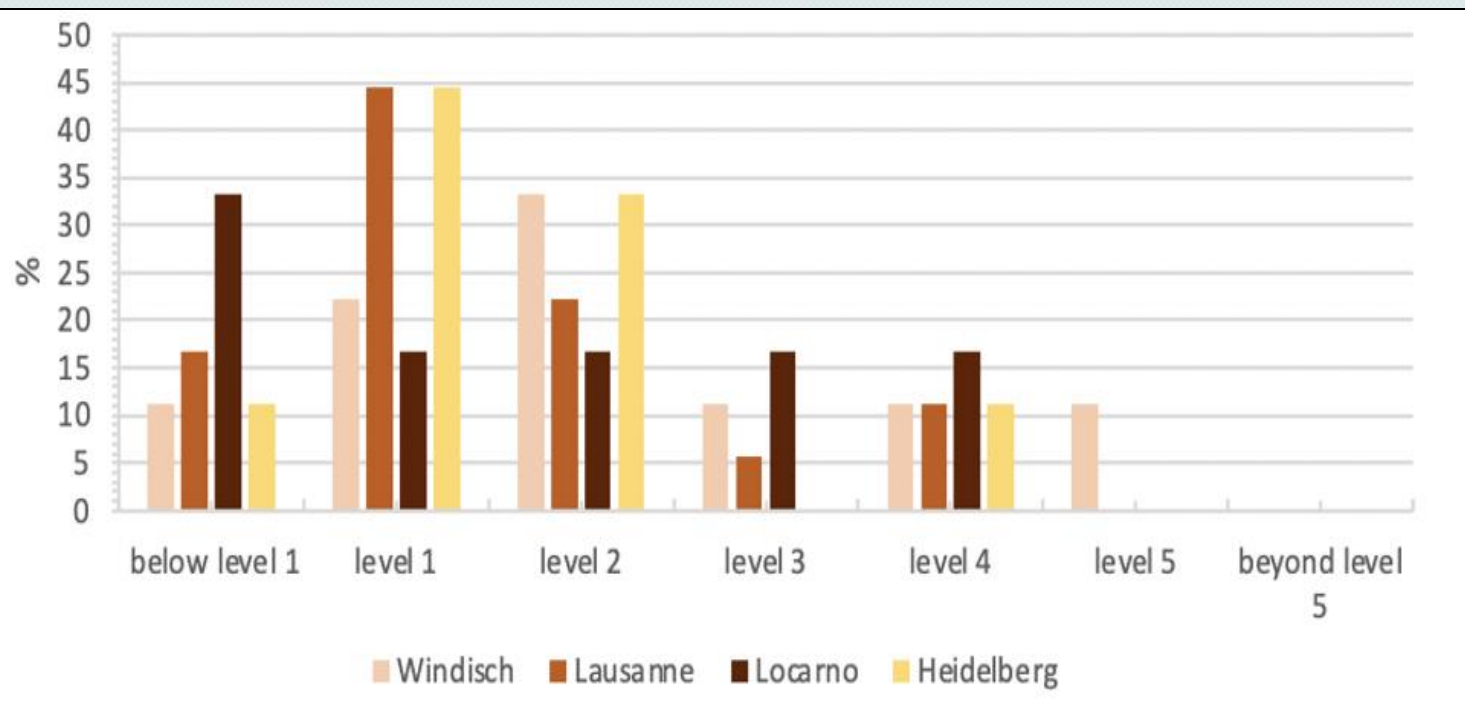

Figure 1.Self-rated level on the YCHANGE Remote Sensing Curriculum before the training event

After summarizing the highest two categories (level 5 and beyond level 5) for the remote sensing curriculum level, all satellite image related items now have a possible score ranging from 1 to 6 . The four satellite related items together had a Cronbach's Alpha of $0.792(n=41)$. Cronbach's Alpha

"[...] is a function of the extent to which items in a test have high communalities and thus low uniquenesses. It is also a function of interrelatedness, although one must remember that this does not imply unidimensionality or homogeneity" [sic] (Cortina, 1993, p. 100).

In general, Cronbach's Alpha values of 0.7 or higher are considered acceptable (Cortina, 1993; George and Mallery, 2003 in Gliem \& Gliem, 2003), although the usefulness of such rules-of-thumb (and Cronbach's Alpha in general) has been debated (see e.g. summary in Viehrig, 2015, pp. 68-69).

A new variable was calculated with SPSS's MEAN function (Table 4). Testing this variable showed that there were no significant differences between participants in Germany and Switzerland (t-test, $d=0.26$ ) or between Swiss language regions (ANOVA).

Competence with regard to analyzing environmental changes. Participants' self-reported competence in analyzing environmental changes was surprisingly low on average, considering that environmental changes are a central part of geography education (Table 4). There were no significant differences between Switzerland and Germany (Mann-Whitney) or between Swiss language regions (Kruskal-Wallis) in this competency.

\section{Does Attending The Training Event Improve Teachers' Self-Reported Competence?}

Unfortunately, the power to detect significant changes for individual training events is low because of the unexpectedly small sample size. Most of the scores did improve, but not all improvements were statistically significant when looking at individual training events (Wilcoxon). Overall, and when looking at Germany vs. Switzerland, all competencies except for job awareness improved significantly (Table 4, Wilcoxon). A surprise is that some participants in Switzerland actually 
self-reported lower competencies after the training event compared to before the event, perhaps as a result of a newfound awareness of what is expected of them and their perceived deficiencies in meeting those expectations. In Switzerland, $4.5 \%$ felt they decreased in their remote sensing curriculum competence level $(n=22), 8.7 \%$ in their ability to work with satellite images by themselves $(n=23)$, $14.3 \%$ in their ability to use satellite images in class $(n=21), 14.3 \%$ in their ability to analyze environmental changes $(n=21)$ and $27.8 \%$ in their job awareness ( $n=18)$. Conversely, $72.7 \%$ felt they improved in their remote sensing curriculum competence level, $47.8 \%$ in their ability to use satellite images by themselves, $71.4 \%$ in their ability to use them in class, $61.9 \%$ in their ability to analyze environmental changes and $33.3 \%$ in their job awareness. In Germany, no participant felt he or she decreased in any of the competency areas evaluated. $100 \%$ felt they improved their remote sensing curriculum competence level $(n=7)$, $100 \%$ their ability to use satellite images by themselves $(n=7), 85.7 \%$ their ability to use them in class $(n=7), 100 \%$ their ability to analyze environmental changes $(n=6)$ and $57.1 \%$ their job awareness $(n=7)$.

There were no significant differences among Swiss language regions (KruskalWallis) for any of the evaluated competencies. Between Germany and Switzerland, there were significant differences in participants' improvement working with satellite images by themselves $(p=0.003)$, using them in class $(p=0.030)$, and analyzing environmental changes ( $p=0.008)$ (Mann-Whitney).

The MEAN score of all competencies related to satellite images improved significantly at all training event locations in Switzerland except Locarno (Windisch $d=2.06$, Lausanne $d=1.06$ and Locarno $d=0.80$; Switzerland overall: $d=0.88$, Table 4). Thus, although the difference in Locarno failed to become significant, the improvement still shows a large effect size. Participants in Germany also improved significantly $(d=2.64)$. There were no significant differences between Swiss language regions in the improvement of the MEAN score (ANOVA). The difference between the MEAN score's improvement in Switzerland and Germany is statistically insignificant ( $p=0.102$, t-test), but shows a large effect size $(d=0.73)$. Thus, teachers improved substantially in their selfreported satellite image-related competence through participating in the training event (total sample: $d=1.04$ ). 
Self-Reported Competence; Values Are In The Format M (SD, Range, n); N.S.= Not Significant

\begin{tabular}{|c|c|c|c|c|c|c|}
\hline & $\begin{array}{c}\text { Competen } \\
\text { ce level } \\
\text { (remote } \\
\text { sensing } \\
\text { curriculum) }\end{array}$ & $\begin{array}{l}\text { Working } \\
\text { with } \\
\text { satellite } \\
\text { images }\end{array}$ & $\begin{array}{l}\text { Using } \\
\text { satellite } \\
\text { images in } \\
\text { class }\end{array}$ & $\begin{array}{l}\text { Analyzing } \\
\text { environ- } \\
\text { mental } \\
\text { changes }\end{array}$ & $\begin{array}{c}\text { Being aware } \\
\text { of jobs that } \\
\text { use remote } \\
\text { sensing }\end{array}$ & $\begin{array}{c}\text { MEAN } \\
\text { Satellite image- } \\
\text { related } \\
\text { competencies }\end{array}$ \\
\hline \multicolumn{7}{|c|}{ Windisch } \\
\hline Before & $\begin{array}{c}3.22 \\
(1.56,1-6,9)\end{array}$ & $\begin{array}{c}3.00 \\
(1.12,1-5,9)\end{array}$ & $\begin{array}{c}2.33 \\
(1.00,1- \\
4,9)\end{array}$ & $\begin{array}{c}2.75 \\
(1.28,1-5,8)\end{array}$ & $\begin{array}{c}3.00 \\
(1.58,1-6,9)\end{array}$ & $\begin{array}{c}2.89 \\
(1.07,1-4.25,9)\end{array}$ \\
\hline After & $\begin{array}{c}3.89 \\
(1.45,2-6,9)\end{array}$ & $\begin{array}{c}3.44 \\
(1.13,2-5,9)\end{array}$ & $\begin{array}{c}3.56 \\
(1.01,2- \\
5.9)\end{array}$ & $\begin{array}{c}3.33 \\
(1.12,2-5,9)\end{array}$ & $\begin{array}{c}3.00 \\
(1.07,2-5,8)\end{array}$ & $\begin{array}{c}3.47 \\
(1.01,2-5,9)\end{array}$ \\
\hline $\begin{array}{l}\text { Differ- } \\
\text { ence } \\
\boldsymbol{p}\end{array}$ & $\begin{array}{c}0.67 \\
(0.50,0-1,9) \\
0.014\end{array}$ & $\begin{array}{c}0.44 \\
(0.73,0-2,9) \\
0.102\end{array}$ & $\begin{array}{c}1.22 \\
(0.83,0- \\
3,9) \\
0.008\end{array}$ & $\begin{array}{c}0.63 \\
(0.74,-1-1,8) \\
0.059\end{array}$ & $\begin{array}{c}0 \\
(0.76,-1-1,8) \\
\text { n.s. }\end{array}$ & $\begin{array}{c}0.58 \\
(0.28,0-1,9) \\
<0.001\end{array}$ \\
\hline \multicolumn{7}{|c|}{ Lausanne } \\
\hline Before & $\begin{array}{c}2.50 \\
(1.20,1- \\
5,18)\end{array}$ & $\begin{array}{c}2.63 \\
(1.46,1- \\
5,19)\end{array}$ & $\begin{array}{c}2.47 \\
(1.22,1- \\
5,19)\end{array}$ & $\begin{array}{c}2.79 \\
(0.86,1- \\
4,19)\end{array}$ & $\begin{array}{c}2.68 \\
(0.89,1-4,19)\end{array}$ & $\begin{array}{c}2.59 \\
(0.87,1.25-4,19)\end{array}$ \\
\hline After & $\begin{array}{c}4.00 \\
(0.82,3-5,7)\end{array}$ & $\begin{array}{c}3.25 \\
(1.04,2-5,8)\end{array}$ & $\begin{array}{c}3.00 \\
(1.07,2- \\
5,8)\end{array}$ & $\begin{array}{c}3.38 \\
(1.06,2-5,8)\end{array}$ & $\begin{array}{c}2.67 \\
(0.82,2-4,6)\end{array}$ & $\begin{array}{c}3.26 \\
(0.95,2-5,8)\end{array}$ \\
\hline $\begin{array}{l}\text { Differ- } \\
\text { ence } \\
\boldsymbol{p}\end{array}$ & $\begin{array}{c}1.29 \\
(0.95,0-2,7) \\
0.034\end{array}$ & $\begin{array}{c}0.38 \\
(0.92,-1- \\
2,8) \\
\text { n.s. }\end{array}$ & $\begin{array}{c}0.25 \\
(0.89,-1- \\
1,8) \\
\text { n.s. }\end{array}$ & $\begin{array}{c}0.38 \\
(0.92,-1-2,8) \\
\text { n.s. }\end{array}$ & $\begin{array}{c}0 \\
(1.10,-1-2,6) \\
\text { n.s. }\end{array}$ & $\begin{array}{c}0.54 \\
(0.65,-0.25- \\
1.75,8) \\
0.051\end{array}$ \\
\hline \multicolumn{7}{|c|}{ Locarno } \\
\hline Before & $\begin{array}{c}2.67 \\
(1.63,1-5,6)\end{array}$ & $\begin{array}{c}2.67 \\
(1.86,1-6,6)\end{array}$ & $\begin{array}{c}2.80 \\
(1.92,1- \\
6,5)\end{array}$ & $\begin{array}{c}2.80 \\
(1.79,1-5,5)\end{array}$ & $\begin{array}{c}2.20 \\
(1.64,1-5,5)\end{array}$ & $\begin{array}{c}2.46 \\
(1.68,1-5.5,6)\end{array}$ \\
\hline After & $\begin{array}{c}4.33 \\
(1.86,2-6,6)\end{array}$ & $\begin{array}{c}3.83 \\
(1.17,2-5,6)\end{array}$ & $\begin{array}{c}4.00 \\
(1.23,2- \\
5,5)\end{array}$ & $\begin{array}{c}3.67 \\
(1.37,2-5,6)\end{array}$ & $\begin{array}{c}4.00 \\
(1.23,2-5,5)\end{array}$ & $\begin{array}{c}3.89 \\
(1.37,2-5.25,6)\end{array}$ \\
\hline $\begin{array}{c}\text { Differ- } \\
\text { ence } \\
\boldsymbol{p}\end{array}$ & $\begin{array}{c}1.67 \\
(2.07,-1- \\
5,6) \\
0.084\end{array}$ & $\begin{array}{c}1.17 \\
(1.94,-2- \\
4,6) \\
\text { n.s. }\end{array}$ & $\begin{array}{c}0.75 \\
(1.89,-2- \\
2,4) \\
\text { n.s. }\end{array}$ & $\begin{array}{c}0.60 \\
(0.89,-1-1,5) \\
\text { n.s. }\end{array}$ & $\begin{array}{c}1.25 \\
(1.71,-1-3,4) \\
\text { n.s. }\end{array}$ & $\begin{array}{c}1.43 \\
(1.79,-1-4.25,6) \\
0.108\end{array}$ \\
\hline \multicolumn{7}{|c|}{ Switzerland overall } \\
\hline Before & $\begin{array}{c}2.73 \\
(1.38,1- \\
6,33)\end{array}$ & $\begin{array}{c}2.74 \\
(1.42,1- \\
6,34)\end{array}$ & $\begin{array}{c}2.48 \\
(1.25,1- \\
6,33)\end{array}$ & $\begin{array}{c}2.78 \\
(1.10,1-5,32)\end{array}$ & $\begin{array}{c}2.70 \\
(1.21,1-6,33)\end{array}$ & $\begin{array}{c}2.65 \\
(1.07,1-5.5,34)\end{array}$ \\
\hline After & $\begin{array}{c}4.05 \\
(1.36,2- \\
6,22)\end{array}$ & $\begin{array}{c}3.48 \\
(1.08,2- \\
5,23)\end{array}$ & $\begin{array}{c}3.45 \\
(1.10,2- \\
5,22)\end{array}$ & $\begin{array}{c}3.43 \\
(1.12,2-5,23)\end{array}$ & $\begin{array}{c}3.16 \\
(1.12,2-5,19)\end{array}$ & $\begin{array}{c}3.51 \\
(1.07,2-5.25,23)\end{array}$ \\
\hline $\begin{array}{l}\text { Differ- } \\
\text { ence } \\
\boldsymbol{p}\end{array}$ & $\begin{array}{c}1.14 \\
(1.25,-1- \\
5,22) \\
0.001\end{array}$ & $\begin{array}{c}0.61 \\
(1.20,-2- \\
4,23) \\
0.028\end{array}$ & $\begin{array}{c}0.76 \\
(1.14,-2- \\
3,21) \\
0.011\end{array}$ & $\begin{array}{c}0.52 \\
(0.81,-1- \\
2,21) \\
0.012\end{array}$ & $\begin{array}{c}0.28 \\
(1.18,-1- \\
3,18) \\
\text { n.s. }\end{array}$ & $\begin{array}{c}0.79 \\
(1.02,-1-4.25,23) \\
0.001\end{array}$ \\
\hline
\end{tabular}

Heidelberg (Germany) 
Schulman, K. et al. (2021). Training teachers to use remote sensing: The YCHANGE project

\begin{tabular}{|c|c|c|c|c|c|c|}
\hline Before & $\begin{array}{c}2.56 \\
(1.13,1-5,9)\end{array}$ & $\begin{array}{c}2.33 \\
(0.87,1-4,9)\end{array}$ & $\begin{array}{c}2.11 \\
(0.78,1- \\
4,9)\end{array}$ & $\begin{array}{c}2.56 \\
(0.73,2-4,9)\end{array}$ & $\begin{array}{c}2.56 \\
(0.73,1-3,9)\end{array}$ & $\begin{array}{c}2.39 \\
(0.61,1.5- \\
3.5,9)\end{array}$ \\
\hline After & $\begin{array}{c}3.57 \\
(0.79,3-5,7)\end{array}$ & $\begin{array}{c}3.86 \\
(0.69,3-5,7)\end{array}$ & $\begin{array}{c}4.00 \\
(0.58,3- \\
5,7)\end{array}$ & $\begin{array}{c}4.00 \\
(0.89,3-5,6)\end{array}$ & $\begin{array}{c}3.14 \\
(0.38,3-4,7)\end{array}$ & $\begin{array}{c}3.64 \\
(0.45,3-4.5,7)\end{array}$ \\
\hline $\begin{array}{c}\text { Differenc } \\
\text { e } \\
p\end{array}$ & $\begin{array}{c}1.43 \\
(0.79,1-3,7) \\
0.014\end{array}$ & $\begin{array}{c}1.86 \\
(0.38,1-2,7) \\
0.011\end{array}$ & $\begin{array}{c}1.86 \\
(1.07,0- \\
3,7) \\
0.026\end{array}$ & $\begin{array}{c}1.83 \\
(0.98,1-3,6) \\
0.026\end{array}$ & $\begin{array}{c}0.71 \\
(0.76,0-2,7) \\
0.059\end{array}$ & $\begin{array}{c}1.46 \\
(0.39,1-2,7) \\
<0.001\end{array}$ \\
\hline \multicolumn{7}{|c|}{ All locations (mean) } \\
\hline Before & $\begin{array}{c}2.69 \\
(1.32,1- \\
6,42)\end{array}$ & $\begin{array}{c}2.65 \\
(1.33,1- \\
6,43)\end{array}$ & $\begin{array}{c}2.40 \\
(1.17,1- \\
6,42)\end{array}$ & $\begin{array}{c}2.73 \\
(1.03,1- \\
5,41)\end{array}$ & $\begin{array}{c}2.67 \\
(1.12,1-6,42)\end{array}$ & $\begin{array}{c}2.59 \\
(0.99,1-5.5,43)\end{array}$ \\
\hline After & $\begin{array}{c}3.93 \\
(1.25,2- \\
6,29)\end{array}$ & $\begin{array}{c}3.57 \\
(1.01,2- \\
5,30)\end{array}$ & $\begin{array}{c}3.59 \\
(1.02,2- \\
5,29)\end{array}$ & $\begin{array}{c}3.55 \\
(1.09,2- \\
5,29)\end{array}$ & $\begin{array}{c}3.15 \\
(0.97,2-5,26)\end{array}$ & $\begin{array}{c}3.54 \\
(0.96,2- \\
5.25,30)\end{array}$ \\
\hline $\begin{array}{c}\text { Differenc } \\
\mathrm{e}\end{array}$ & $\begin{array}{c}1.21 \\
(1.15,-1- \\
5,29)\end{array}$ & $\begin{array}{c}0.90 \\
(1.18,-2- \\
4,30)\end{array}$ & $\begin{array}{c}1.04 \\
(1.20,-2- \\
3,28)\end{array}$ & $\begin{array}{c}0.81 \\
(1.00,-1- \\
3,27)\end{array}$ & $\begin{array}{c}0.40 \\
(1.08,-1- \\
3,25)\end{array}$ & $\begin{array}{c}0.95 \\
(0.95,-1- \\
4.25,30)\end{array}$ \\
\hline$p$ & $<0.001$ & 0.001 & 0.001 & 0.001 & 0.074 & $<0.001$ \\
\hline
\end{tabular}

There were two comments from Lausanne:

- "For this presentation there, the exercise was difficult to access" (translated) and

- "Since the documents did not work with Safari, it was useless to do that. Because the demanded exercises were unfeasible. One should have anticipated this problem. Therefore, I didn't even understand what the site was for that we had to use. For Google Earth, this software is very interesting, but I didn't learn anything during the lesson about remote sensing" (translated).

The second comment shows that some teachers might have the same misconception as some of the students in Kollar's study (2012), i.e., not realizing that Google Earth uses satellite images, and, therefore, remote sensing data. Both comments mention technical issues, which might explain the lower improvement and ratings of the Lausanne group.

\section{How Do Teachers See The Curriculum, The Sample Projects, Student Projects, Web Platform, BLIF And Training Event? Are There Differences Between Participants In Different Countries? Are There Differences Between Participants In Different Language Regions Within Switzerland?}

Web platform use. The web platform received limited uptake during the runtime of the project. As of July 14, 2019, the platform had 947 registered users. However, many of them were likely spam or had no interest in the project, as indicated by the administrators repeatedly needing to delete posts advertising a variety of links and products from "Toon Blast Hack" to swim suits. Various groups were created on the project web site, e.g., containing information relevant specifically to one country. There is no information available about how many users were actual teachers or students. Not a single student project was published to the site. The web platform team enabled Google Analytics to get information about site usage. The analytics data was puzzling, however, which 
makes it of little to no use. It showed a lesser number of views of the registration page than the number of the platform's actual registered users. Consequently, the analytics data will not be reported or evaluated here.

Curriculum evaluation. Participants had to evaluate the project's remote sensing curriculum. They scored statements on a scale from 1 ("I don't agree at all") to 6 ("I fully agree").

The results, e.g., in terms of perceived usefulness, were very different between the German and Italian speaking regions of Switzerland on the one hand vs. the French speaking region of Switzerland on the other hand. Kruskal-Wallis-tests showed the differences between the Swiss language regions to be significant in each of the statements evaluated in the questionnaire (in the order shown in Table 5: $p=0.001, p=0.001, p=0.003, p=0.005, p=0.008)$. There were significant differences in the evaluations of the statements between cohorts in Windisch and Lausanne (in the order shown in Table 5: $p=0.003, p=0.009, p=0.007, p=0.019$, $p=0.041$ ), while between cohorts in Locarno and Windisch there was no statistically significant difference (Mann-Whitney). There was also no significant difference in statement evaluations between the cohorts in Germany and Switzerland (in the order shown in Table 5: $p=0.077, p=$ n.s., $p=$ n.S., $p=0.072$, $p=$ n.s.; Mann-Whitney). At all of the training events, the statement relating to grade level recommendations received the lowest rating compared to the other curriculum statements.

Table 5

Curriculum Evaluation

\begin{tabular}{|c|c|c|c|c|c|}
\hline $\begin{array}{l}\text { Statements } \\
\text { evaluated }\end{array}$ & $\begin{array}{c}\text { Windisch } \\
\boldsymbol{M}(\boldsymbol{S} D, \\
\text { range, } \boldsymbol{n})\end{array}$ & $\begin{array}{c}\text { Lausanne } \\
\boldsymbol{M}(\boldsymbol{S} \boldsymbol{D}, \\
\text { range, } \boldsymbol{n})\end{array}$ & $\begin{array}{c}\text { Locarno } \\
M(S D, \\
\text { range, } n)\end{array}$ & $\begin{array}{c}\text { Switzerland } \\
\text { overall } \\
M(S D, \text { range, } \\
n)\end{array}$ & $\begin{array}{l}\text { Heidelberg } \\
M(S D, \\
\text { range, } n)\end{array}$ \\
\hline $\begin{array}{l}\text { The curriculum is } \\
\text { useful for teaching } \\
\text { remote sensing in } \\
\text { school }\end{array}$ & $\begin{array}{c}4.25 \\
(0.89,3-6,8)\end{array}$ & $\begin{array}{c}2.82 \\
(1.13,1-6 \\
17)\end{array}$ & $\begin{array}{c}4.50 \\
(0.55,4-5,6)\end{array}$ & $\begin{array}{c}3.52 \\
(1.24,1-6,31)\end{array}$ & $\begin{array}{c}4.56 \\
(1.74,2-6,9)\end{array}$ \\
\hline $\begin{array}{l}\text { The curriculum is } \\
\text { easy to } \\
\text { read/understand. } \\
\text { The learning }\end{array}$ & $\begin{array}{c}4.75 \\
(1.04,3-6,8)\end{array}$ & $\begin{array}{c}3.18 \\
(1.29,1-5 \\
17)\end{array}$ & $\begin{array}{c}5.40 \\
(0.55,5-6,5)\end{array}$ & $\begin{array}{c}3.97 \\
(1.45,1-6,30)\end{array}$ & $\begin{array}{c}4.67 \\
(1.58,2-6,9)\end{array}$ \\
\hline $\begin{array}{l}\text { progression from } \\
\text { one competence } \\
\text { level to another } \\
\text { makes sense. }\end{array}$ & $\begin{array}{c}4.50 \\
(0.93,3-6,8)\end{array}$ & $\begin{array}{c}3.07 \\
(1.16,1-5 \\
15)\end{array}$ & $\begin{array}{c}4.67 \\
(0.52,4-5,6)\end{array}$ & $\begin{array}{c}3.79 \\
(1.24,1-6,29)\end{array}$ & $\begin{array}{c}4.22 \\
(1.64,2-6,9)\end{array}$ \\
\hline $\begin{array}{l}\text { The learning } \\
\text { progression from } \\
\text { one approach to } \\
\text { another makes } \\
\text { sense. }\end{array}$ & $\begin{array}{c}4.38 \\
(1.06,3-6,8)\end{array}$ & $\begin{array}{c}3.06 \\
(1.18,1-5 \\
16)\end{array}$ & $\begin{array}{c}4.67 \\
(0.52,4-5,6)\end{array}$ & $\begin{array}{c}3.73 \\
(1.26,1-6,30)\end{array}$ & $\begin{array}{c}4.67 \\
(1.12,3-6,9)\end{array}$ \\
\hline $\begin{array}{l}\text { The } \\
\text { recommendations } \\
\text { for grade levels fit } \\
\text { with students' } \\
\text { abilities. }\end{array}$ & $\begin{array}{c}3.86 \\
(1.22,3-6,7)\end{array}$ & $\begin{array}{c}2.57 \\
(1.22,1-5 \\
14)\end{array}$ & $\begin{array}{c}4.50 \\
(0.84,3-5,6)\end{array}$ & $\begin{array}{c}3.33 \\
(1.39,1-6,27)\end{array}$ & $\begin{array}{c}4.22 \\
(1.39,2-6,9)\end{array}$ \\
\hline MEAN score & $\begin{array}{c}4.34 \\
(0.84,3.4-6 \\
8)\end{array}$ & $\begin{array}{c}2.96 \\
(1.04,1- \\
5.2,18)\end{array}$ & $\begin{array}{c}4.73 \\
(0.45,4- \\
5.2,6)\end{array}$ & $\begin{array}{c}3.64 \\
(1.19,1-6,32)\end{array}$ & $\begin{array}{c}4.47 \\
(1.27,2.6- \\
6,9)\end{array}$ \\
\hline
\end{tabular}


All five of the curriculum-related statements evaluated in the questionnaire together had a Cronbach's Alpha of $0.945(n=35)$. A new variable was calculated with SPSS's MEAN function (Table 5). Overall, the average score was 3.82 $(S D=1.24$, range $1-6, n=41)$, indicating a somewhat positive view of the curriculum. There was no statistically significant difference between the responses from Germany and Switzerland ( $p=0.076$, t-test), but the effect size was large $(d=0.69)$. This indicates that participants in Germany did evaluate the curriculum more positively than participants in Switzerland. Among the Swiss language regions, there was a significant difference in responses $(p<0.001$, ANOVA). Specifically, results from Windisch were significantly different from those from Lausanne ( $p=0.003$, t-test), while there was no statistically significant difference in results between Locarno and Windisch (t-test).

There were three comments:

- "The curricula goes way to far for the secondary one level (12 to 15), and we wouldn't use level 5 (and even level 4) in class at this stage. We usually work with this kind of tools on a subject, and not in itself (we don't work on a tool for the sake of the tool, but as a tool helping to solve a geographical questions), but it is interesting to have a curricula as a background" [sic] (Lausanne).

- "do not quite understand these questions" (translated, Windisch)

- "no possibility not to answer, if one doesn't have a clue about a statement" (translated, Heidelberg).

Evaluation of the sample projects. Participants had to state which sample projects they worked with during the training event. In Lausanne and Locarno, participants worked with the "The Aletsch glacier" sample project, which followed a different format than the other sample projects (e.g., it included worksheets with printouts of satellite images and worksheets using Google Earth, working on one topic with different levels). In Windisch, participants also stated that they worked with the Aletsch glacier example, but that was before it had been put into the sample project format by the Swiss project group. Rather, in this pre-release stage, it consisted only of individual exercises within the presentation. In Heidelberg, participants worked with their own Costa Rica banana plantation example, which was not even part of the YCHANGE sample projects.

Participants had to state in which grade level they thought the sample project fit. This was an open response question. For Switzerland, Grades 7-9 can be summarized as Sec 1 and Grades 10 through 12 or 13 can be summarized as Sec 2, although this might not be the case in all cantons. Three respondents in Switzerland thought the sample project was suitable for Sec 1, 13 respondents thought it was suitable for $\operatorname{Sec} 2$, and one respondent thought it was suitable for both Sec 1 and Sec 2. One respondent each put in the numbers 3 or 5 , which could mean Grades 3 or 5, but more likely refers to Grades 9 and 11, being that some schools in Switzerland start counting again from Grade 7 (i.e., the $1^{\text {st }}$ secondary grade, as opposed to the $1^{\text {st }}$ primary grade). Two respondents wrote in Gymnasium. This response begs clarification because Gymnasium sometimes starts in lower secondary school (Sec 1), but more frequently it starts in higher secondary school (Sec 2). One respondent wrote that working with Google Earth would be suitable in Sec 1, while BLIF would only be suitable for Sec 2 "or not at all". There were 16 participants who failed to respond. In Germany, one 
respondent chose Grades 10-12, one respondent chose Grades 5-10, five respondents chose Grades 7-8, one respondent chose Grades 7-10 and one participant failed to respond. A direct comparison between Germany and Switzerland is difficult as the Swiss example had a somewhat different structure, but the data seems to confirm the informal impression that teachers in Germany seem to see BLIF as more suitable for school, even for middle school, than in Switzerland.

Participants also had to rate different elements of the sample project ("In the sample project there's ...") on a scale of 1 ("way too little") to 5 ("way too much"), i.e., the ideal range was between 2.5 and 3.5. Based on these scores, the sample project was received very positively in Switzerland (Table 6). In Germany, respondents indicated, on average, that there was a bit too much text. Only the differences between Germany and Switzerland with regard to text $(p=0.013)$ and pictures $(p=0.046)$ were statistically significant (Mann-Whitney). Whereas Kruskal-Wallis tests showed no statistically significant differences among the Swiss language regions.

All six items together had a Cronbach's Alpha of 0.843 ( $n=29)$. A new variable was calculated with SPSS's MEAN function (Table 6). Overall, the MEAN score average was $3.04(S D=0.59$, range $1.75-5, n=34)$, indicating that on average participants thought the sample projects were just right. There were no significant differences between Germany and Switzerland (Mann-Whitney) or among the Swiss language regions (Kruskal-Wallis).

Table 6

Evaluation of the Sample Projects

\begin{tabular}{|c|c|c|c|c|c|}
\hline Item & $\begin{array}{l}\text { Windisch } \\
M(S D, \\
\text { range, } n)\end{array}$ & $\begin{array}{l}\text { Lausanne } \\
M(S D, \\
\text { range, } n)\end{array}$ & $\begin{array}{l}\text { Locarno } \\
M(S D, \\
\text { range, } n)\end{array}$ & $\begin{array}{l}\text { Switzerland } \\
\text { overall } \\
M(S D \text {, range, } \\
n)\end{array}$ & $\begin{array}{l}\text { Heidelberg } \\
M(S D \text {, range, } \\
\text { n) }\end{array}$ \\
\hline Text & $\begin{array}{l}3.00 \\
(0.50,2-4.9)\end{array}$ & $\begin{array}{l}2.50 \\
(0.97,2-5,10)\end{array}$ & $\begin{array}{l}2.50 \\
(1.05,1-4.6)\end{array}$ & $\begin{array}{l}2.68 \\
(0.85,1-5,25)\end{array}$ & $\begin{array}{l}3.63 \\
(0.92,3-5.8)\end{array}$ \\
\hline Pictures & $\begin{array}{l}3.11 \\
(0.33,3-4,9)\end{array}$ & $\begin{array}{l}3.13 \\
(0.84,2-5,8)\end{array}$ & $\begin{array}{l}3.50 \\
(0.55,3-4,6)\end{array}$ & $\begin{array}{l}3.22 \\
(0.60,2-5,23)\end{array}$ & $\begin{array}{l}2.75 \\
(0.46,2-3,8)\end{array}$ \\
\hline $\begin{array}{l}\text { Satellite } \\
\text { image tasks } \\
\text { Tasks }\end{array}$ & $\begin{array}{l}3.11 \\
(0.33,3-4,9)\end{array}$ & $\begin{array}{l}2.90 \\
(0.88,2-5,10)\end{array}$ & $\begin{array}{l}3.33 \\
(0.52,3-4,6)\end{array}$ & $\begin{array}{l}3.08 \\
(0.64,2-5,25)\end{array}$ & $\begin{array}{l}3.00 \\
(0,3,7)\end{array}$ \\
\hline $\begin{array}{l}\text { focused on } \\
\text { the content } \\
\text { topic }\end{array}$ & $\begin{array}{l}3.00 \\
(0,3,9)\end{array}$ & $\begin{array}{l}2.89 \\
(0.93,2-5,9)\end{array}$ & $\begin{array}{l}3.17 \\
(0.41,3-4,6)\end{array}$ & $\begin{array}{l}3.0 \\
(0.59,2-5,24)\end{array}$ & $\begin{array}{l}3.00 \\
(0,3,7)\end{array}$ \\
\hline $\begin{array}{l}\text { Background } \\
\text { information }\end{array}$ & $\begin{array}{l}3.00 \\
(0.87,1-4,9)\end{array}$ & $\begin{array}{l}2.78 \\
(1.20,1-5,9)\end{array}$ & $\begin{array}{l}2.83 \\
(0.75,2-4,6)\end{array}$ & $\begin{array}{l}2.88 \\
(0.95,1-5,24)\end{array}$ & $\begin{array}{l}3.13 \\
(0.64,2-4,8)\end{array}$ \\
\hline $\begin{array}{l}\text { Step-by- } \\
\text { step } \\
\text { quidelines }\end{array}$ & $\begin{array}{l}2.89 \\
(0.33,2-3,9)\end{array}$ & $\begin{array}{l}3.18 \\
(0.98,2-5,11)\end{array}$ & $\begin{array}{l}3.50 \\
(0.55,3-4,6)\end{array}$ & $\begin{array}{l}3.15 \\
(0.73,2-5,26)\end{array}$ & $\begin{array}{l}3.13 \\
(0.84,2-5,8)\end{array}$ \\
\hline MEAN score & $\begin{array}{l}3.02 \\
(0.31,2.33- \\
3.5,9)\end{array}$ & $\begin{array}{l}2.93 \\
(0.92 \\
5,11)\end{array}$ & $\begin{array}{l}3.14 \\
(0.48,2.67- \\
4,6)\end{array}$ & $\begin{array}{l}3.01 \\
(0.65,1.75- \\
5,26)\end{array}$ & $\begin{array}{l}3.11 \\
(0.34,2.5- \\
3.67,8)\end{array}$ \\
\hline
\end{tabular}

Participants were also asked to rate the sample project overall on a scale from 1 ("I really hated it") to 6 ("I really loved it"). Originally, the question had space to rate three different sample projects to accommodate the possibility of training 
events looking at more than one sample project. Since only one sample project was ultimately used, the ratings of those teachers who filled out more than one of the spaces allotted on the form (e.g., differentiating between different parts of the "Aletsch glacier" example, but usually just entering the same value) were averaged. Overall, participants in both Switzerland and Germany rated the sample project rather favorably (Table 7 , overall $M=4.31, S D=1.28$, range 1-6, $n=32$ ). There were no significant differences in responses between participants in Germany and Switzerland ( $p=0.064$, Mann-Whitney), but there were statistically significant differences between responses of participants in the various Swiss language regions ( $p<0.001$, Kruskal-Wallis). Using pairwise comparison, we found a significant difference between Windisch and Lausanne $(p=0.001)$, but not between Windisch and Locarno (Mann-Whitney).

Table 7

Overall Rating of Sample Projects

\begin{tabular}{|c|c|c|c|c|c|}
\hline Item & $\begin{array}{l}\text { Windisch } \\
\boldsymbol{M}(\boldsymbol{S} \boldsymbol{D}, \\
\text { range, } \boldsymbol{n})\end{array}$ & $\begin{array}{l}\text { Lausanne } \\
\boldsymbol{M}(\boldsymbol{S} D, \\
\text { range, } n)\end{array}$ & $\begin{array}{l}\text { Locarno } \\
M(S D, \\
\text { range, } n)\end{array}$ & $\begin{array}{l}\text { Switzerland } \\
\text { overall } \\
M(S D \text {, range, } n)\end{array}$ & $\begin{array}{l}\text { Heidelberg } \\
M(S D, \\
\text { range, } n)\end{array}$ \\
\hline Rating & $\begin{array}{l}4.67 \\
(0.87,4-6 \text {, } \\
9)\end{array}$ & $\begin{array}{l}3.00 \\
(0.82,1-4, \\
10)\end{array}$ & $\begin{array}{l}5.17 \\
(0.41,5-6, \\
6)\end{array}$ & $\begin{array}{l}4.12 \\
(1.20,1-6,25)\end{array}$ & $\begin{array}{l}5.00 \\
(1.41,2-6, \\
7)\end{array}$ \\
\hline
\end{tabular}

There is a discrepancy between the results of Table 6 and 7 . It could be that the average values which were barely in the ideal range, such as the 2.5 for 'text' from Locarno and Lausanne, had a substantial impact on participant's overall ratings. Alternatively, this could be the effect of other variables at play that impacted participants' overall ratings, which had not been included in Table 6.

There were several comments. In Windisch, one respondent commented that "I am a little bit slow in understanding IT-tasks", and another that "Nicole Notter has done the presentation very well and was responsive to individual questions" (both translated). In Lausanne, one commented that "Sample project 1: interesting, but I'm not sure I understood what the real advantage of doing it on google earth rather than on a printed picture was (legends can be added, distances calculated...). The profile function was interesting. Sample project 2: interesting for us as teachers to understand better how the wellenlänge [wave length] worked, but too specialized to be used in class (uses a lot of time for something that we don't have in the curriculum we have to follow" [sic]. Another commented "I think the pupils need to have a certain knowledge on a level superior to that of the obligatory school (wavelength, visible spectrum etc.) to comprehend the utility of the exercise" (translated). A third Lausanne participant commented that "Using the BLIF software is quite complex. Maybe too much for classroom use. Tools more for the intention of teachers than that of pupils" (translated). There were no comments from Locarno. Heidelberg had only one comment, complaining about a "spelling mistake in the first task" (translated).

Student project evaluation. Respondents had to agree or disagree with statements about the student projects on a scale from 1 ("I don't agree at all") to 6 ("I agree fully") (Table 8). One comment from Lausanne was "We didn't have time to address this", which might explain the lower rating from the Lausanne group. In Germany, one comment pointed out a spelling mistake and also complained about "no possibility of no answer" (translated). The two student 
project-related items had a Cronbach's Alpha of 0.891 ( $n=33)$. A new variable was calculated with SPSS's MEAN function (Table 8). Overall, the average was $3.86(S D=1.18$, range $2-6, n=33)$. There were no statistically significant differences between responses from participants in Germany and Switzerland (Mann-Whitney), but there were among participants in the various Swiss language regions ( $p<0.001$, Kruskal-Wallis). Mann-Whitney tests showed that there were significant differences between respondents in Windisch and Locarno $(p=0.007)$ and between respondents in Windisch and Lausanne $(p=0.002)$.

Table 8

Student Project Evaluation

\begin{tabular}{|c|c|c|c|c|c|}
\hline Item & $\begin{array}{c}\text { Windisch } \\
M(S D, \\
\text { range, } n)\end{array}$ & $\begin{array}{c}\text { Lausanne } \\
M(S D, \\
\text { range, } n)\end{array}$ & $\begin{array}{l}\text { Locarno } \\
M(S D, \\
\text { range, } n)\end{array}$ & $\begin{array}{c}\text { Switzerland } \\
\text { overall } \\
\mathbf{M}(\mathbf{S D}, \text { range, } n)\end{array}$ & $\begin{array}{c}\text { Heidelberg } \\
\boldsymbol{M}(\boldsymbol{S} D, \\
\text { range, } n)\end{array}$ \\
\hline $\begin{array}{l}\text { The information } \\
\text { on how to create } \\
\text { a student project } \\
\text { is helpful. }\end{array}$ & $\begin{array}{c}4.22 \\
(0.67,3-5,9)\end{array}$ & $\begin{array}{c}2.80 \\
(1.03,2-5,10)\end{array}$ & $\begin{array}{c}5.17 \\
(0.75,4-6,6)\end{array}$ & $\begin{array}{c}3.88 \\
(1.27,2-6,25)\end{array}$ & $\begin{array}{c}4.25 \\
(1.28,2-6,8)\end{array}$ \\
\hline $\begin{array}{l}\text { The } \\
\text { requirements for } \\
\text { student projects } \\
\text { are clear }\end{array}$ & $\begin{array}{c}4.00 \\
(0.50,3-5,9)\end{array}$ & $\begin{array}{c}2.70 \\
(0.82,2-4,10)\end{array}$ & $\begin{array}{c}5.17 \\
(0.754-6,6)\end{array}$ & $\begin{array}{c}3.76 \\
(1.20,2-6,25)\end{array}$ & $\begin{array}{c}3.75 \\
(1.39,2-6,8)\end{array}$ \\
\hline MEAN score & $\begin{array}{c}4.11 \\
(0.55,3-5,9)\end{array}$ & $\begin{array}{c}2.75 \\
(0.75,2-4,10)\end{array}$ & $\begin{array}{c}5.17 \\
(0.68,4.5- \\
6,6)\end{array}$ & $\begin{array}{c}3.82 \\
(1.17,2-6,25)\end{array}$ & $\begin{array}{c}4.00 \\
(1.28,2-6,8)\end{array}$ \\
\hline
\end{tabular}

Evaluation of the web platform. Respondents had to agree or disagree with several statements about the web platform on a scale from 1 ("I don't agree at all") to 6 ("I fully agree"). Overall, the averages were above 3.5 for all items and thus quite positive (Table 9). Again, participants from the French speaking area of Switzerland were considerably more critical in their rating of each statement than those from the other two Swiss language regions. While the differences in responses among the Swiss language regions were statistically significant (in the order shown in Table 9: $p=0.001, p=0.003, p=0.003, p=0.004, p=0.036$, KruskalWallis), there were no significant differences between Germany and Switzerland in most of the individual items (in the order shown in Table 9: $p=n . s ., p=0.044$, $p=0.079, p=$ n.s., $p=0.054$, Mann-Whitney). Mann-Whitney-tests showed that there were statistically significant differences between Windisch and Locarno (in the order shown in Table 9: $p=0.016, p=0.016, p=0.010, p=$.s., $p=0.062$ ) and between Windisch and Lausanne (in the order shown in Table 9: $p=0.020$, $p=0.068, p=0.047, p=0.009$, $p=$ n.s.).

One respondent in Windisch commented: "For me it would need more help. But that's due to me." (translated). In Lausanne, one respondent wrote: "We didn't have time to address this, but will look into it with interest!". This lack of time might explain the lower scores from the Lausanne group on this section of the questionnaire.

The five web platform items had a Cronbach's Alpha of $0.936(n=27)$. A new variable was calculated with SPSS's MEAN function (Table 9). Overall, the average was $4.04(S D=1.17$, range $1.8-6, n=32)$. There were no statistically significant differences in responses between participants in Germany and Switzerland ( $p=0.099$, t-test), but there were among the Swiss language regions 
Schulman, K. et al. (2021). Training teachers to use remote sensing: The YCHANGE project

$(p<0.001$, ANOVA). Pairwise analysis showed significant differences between Locarno and Windisch ( $p=0.008)$ and between Windisch and Lausanne $(p=0.011)$ (t-test).

Table 9

Evaluation of the Web Platform

\begin{tabular}{|c|c|c|c|c|c|}
\hline Item & $\begin{array}{l}\text { Windisch } \\
M(S D, \\
\text { range, } n)\end{array}$ & $\begin{array}{c}\text { Lausanne } \\
M(S D, \text { range } \\
\text { n) }\end{array}$ & $\begin{array}{l}\text { Locarno } \\
M(S D, \\
\text { range, } n)\end{array}$ & $\begin{array}{c}\text { Switzerland } \\
\text { overall } \\
M(S D, \text { range, } \\
\text { n) }\end{array}$ & $\begin{array}{c}\text { Heidelberg } \\
\boldsymbol{M}(\boldsymbol{S} \boldsymbol{D}, \\
\text { range, } \boldsymbol{n})\end{array}$ \\
\hline $\begin{array}{l}\text { Everything I need } \\
\text { is on the web } \\
\text { platform. }\end{array}$ & $\begin{array}{l}4.11 \\
(0.60,3-5,9)\end{array}$ & $\begin{array}{l}2.89 \\
(1.17,1-4,9)\end{array}$ & $\begin{array}{l}5.17 \\
(0.75,4-6,6)\end{array}$ & $\begin{array}{l}3.92 \\
(1.25,1-6,24)\end{array}$ & $\begin{array}{l}4.43 \\
(1.27,2-6,7)\end{array}$ \\
\hline $\begin{array}{l}\text { The web platform } \\
\text { is easy to } \\
\text { navigate }\end{array}$ & $\begin{array}{l}3.67 \\
(1.00,2-5,9)\end{array}$ & $\begin{array}{l}2.80 \\
(1.03,2-5,10)\end{array}$ & $\begin{array}{l}5.00 \\
(0.63,4-6,6)\end{array}$ & $\begin{array}{l}3.64 \\
(1.25,2-6,25)\end{array}$ & $\begin{array}{l}4.71 \\
(1.25,2-6,7)\end{array}$ \\
\hline $\begin{array}{l}\text { The web platform } \\
\text { has an appealing } \\
\text { layout }\end{array}$ & $\begin{array}{l}3.89 \\
(0.78,3-5,9)\end{array}$ & $\begin{array}{l}2.75 \\
(1.28,1-5,8)\end{array}$ & $\begin{array}{l}5.33 \\
(0.82,4-6,6)\end{array}$ & $\begin{array}{l}3.87 \\
(1.39,1-6,23)\end{array}$ & $\begin{array}{l}4.86 \\
(1.35,2-6,7)\end{array}$ \\
\hline $\begin{array}{l}\text { The web platform } \\
\text { is easy to use } \\
\text { (e.g. registration). }\end{array}$ & $\begin{array}{l}4.56 \\
(1.24,2-6,9)\end{array}$ & $\begin{array}{l}2.78 \\
(0.97,2-5,9)\end{array}$ & $\begin{array}{l}5.00 \\
(0.63,4-6,6)\end{array}$ & $\begin{array}{l}4.00 \\
(1.38,2-6,24)\end{array}$ & $\begin{array}{l}4.43 \\
(1.27,2-6,7)\end{array}$ \\
\hline $\begin{array}{l}\text { The tutorials are } \\
\text { helpful. }\end{array}$ & $\begin{array}{l}3.86 \\
(0.90,3-5,7)\end{array}$ & $\begin{array}{l}3.33 \\
(1.12,2-5,9)\end{array}$ & $\begin{array}{l}5.00 \\
(1.10,3-6,6)\end{array}$ & $\begin{array}{l}3.95 \\
(1.21,2-6,22)\end{array}$ & $\begin{array}{l}5.00 \\
(1.41,2-6,7)\end{array}$ \\
\hline MEAN score & $\begin{array}{l}4.01 \\
(0.71,2.8-5,9)\end{array}$ & $\begin{array}{l}2.97 \\
(0.85,1.8- \\
4.4,10)\end{array}$ & $\begin{array}{l}5.10 \\
(0.58,4.6- \\
6,6)\end{array}$ & $\begin{array}{l}3.86 \\
(1.11,1.8-6,25)\end{array}$ & $\begin{array}{l}4.69 \\
(1.25,2-6,7)\end{array}$ \\
\hline
\end{tabular}

Evaluation of BLIF. Respondents had to agree or disagree with several statements about BLIF on a scale from 1 ("I don't agree at all") to 6 ("I fully agree") (Table 10). Items 1 (understandable) and 6 (instructions) were just barely normally distributed (Kolmogorov-Smirnov, $p=0.054, p=0.059$ ). In order to not have to switch statistical tests, all individual items were evaluated with nonparametric tests.

The differences among the Swiss language regions were significant for each item (in order of Table 10: $p=0.020, p=0.007, p=0.015, p=0.006, p<0.001$, $p=0.017, p=0.001, p=0.001$, Kruskal-Wallis). There were statistically significant differences between Locarno and Windisch for nearly all items (in the order shown in Table 10: $p=0.025, p=0.040, p=0.038, p=0.034, p=0.026, p=0.059$, $p=0.041, p=0.057)$. There were significant differences between Windisch and Lausanne for BLIF having all needed tools $(p=0.006)$, technical problems $(p=0.031)$ and BLIF being a great software $(p=0.006)$ (Mann-Whitney). Regarding Switzerland vs. Germany, there were no statistically significant differences between participants' rating of ease of understanding how to analyze satellite images with or navigating BLIF, as well as BLIF having all needed tools (MannWhitney). The other items show a significantly lower rating by participants in Switzerland (layout $p=0.021$, easy to use the BLIF tools $p=0.028$, instructions $p=0.026$, technical problems $p=0.024$, great software $p=0.006$, Mann-Whitney).

The eight items had a Cronbach's Alpha of $0.944(n=31)$. A new variable was calculated with SPSS's MEAN function (Table 10). Overall, the average was 3.78 $(S D=1.19$, range 1.57-6, $n=35)$. Participants in Switzerland rated BLIF significantly lower than those in Germany $(p=0.032$, Mann-Whitney). This 
corroborates informal experiences. There were also statistically significant differences among Swiss language regions ( $p<0.001$, Kruskal-Wallis). Lausanne participants rated BLIF significantly lower than Windisch participants $(p=0.025)$, and Windisch participants rated BLIF significantly lower than those in Locarno $(p=0.008)$ (Mann-Whitney).

Table 10

Evaluation of BLIF

\begin{tabular}{llllll}
\hline Item & $\begin{array}{l}\text { Windisch } \\
\boldsymbol{M}(\boldsymbol{S D}, \text { range, } \\
\end{array}$ & $\begin{array}{l}\text { Lausanne } \\
\boldsymbol{M}(\mathbf{S} \boldsymbol{D}, \text { range, } \\
\boldsymbol{n})\end{array}$ & $\begin{array}{l}\text { Locarno } \\
\boldsymbol{M}(\boldsymbol{S} \boldsymbol{D}, \\
\text { range, } \boldsymbol{n})\end{array}$ & $\begin{array}{l}\text { Switzerland } \\
\text { overall } \\
\boldsymbol{M}(\boldsymbol{S} \boldsymbol{D}, \text { range, } \\
\boldsymbol{n})\end{array}$ & $\begin{array}{l}\text { Heidelberg } \\
\boldsymbol{M}(\boldsymbol{S} \boldsymbol{D},\end{array}$ \\
range, $\boldsymbol{n})$
\end{tabular}

The three comments received were all from Lausanne: "I had problems, and I'm not the only one, to be able to access the manual tool to perform the categories (with Safari)" (translated), "As said, very interesting as a teacher, too specialized for schools in our part of Switzerland. And: it should be specified what navigator it has to be used in, and quite a few technical problems occur." [sic] and "time to refresh could be long" [sic].

Training event evaluation. Respondents had to agree or disagree with several statements about the training event on a scale from 1 ("I don't agree at all") to 6 ("I fully agree"). They also had to rate the training event duration (too long, just right, too short) (Table 11). Items 6 (unanswered questions) and 8 (prepared to do sample projects) were normally distributed (Kolmogorov- 
Schulman, K. et al. (2021). Training teachers to use remote sensing: The YCHANGE project

Smirnov, $p=0.094, p=0.151)$. In order to not have to switch statistical tests, all individual items were evaluated with non-parametric tests.

Nearly all individual items showed significant differences among the Swiss language regions (in the order shown in Table 11: $p=0.003, p=0.084, p=0.002$, $p=0.006, p=0.002, p=0.070, p=0.012, p=0.019, p=0.016, p=$ n.s., Kruskal-Wallis). There were significant differences between Windisch and Locarno (in the order shown in Table 11: $p=0.085, p=$ n.S., $p=0.064, p=$ n.S., $p=$ n.S., $p=0.018, p=$ n.s., $p=0.054, p=0.022, p=$ n.s.) and between Windisch and Lausanne (in the order shown in Table 11: $p=0.012, p=0.049, p=0.017, p=0.003, p=0.002, p=$ n.S., $p=0.007, p=$ n.s., $p=$ n.s., $p=$ n.s.) for some items (Mann-Whitney). Participants in Switzerland and Germany differed significantly in how helpful they thought the training event was for their teaching $(p=0.005)$, how many unanswered questions they still had $(p=0.040)$ and in feeling prepared to do their own student project $(p=0.013)$. Significance values for reaching the objectives of the training event $(p=0.078)$ and the structure of the training event $(p=0.066)$ were less than $p=0.1$ (which is considered significant according to some authors, although the more common cut-off is $p=0.05$, see e.g., discussion in Viehrig, 2015), the other items were above.

Table 11

Training Event Evaluation

\begin{tabular}{|c|c|c|c|c|c|}
\hline Item & $\begin{array}{l}\text { Windisch } \\
M(S D, \\
\text { range, } n)\end{array}$ & $\begin{array}{l}\text { Lausanne } \\
M(S D, \\
\text { range, } n)\end{array}$ & $\begin{array}{l}\text { Locarno } \\
M(S D, \\
\text { range, } n)\end{array}$ & $\begin{array}{l}\text { Switzerland } \\
\text { overall } \\
M(S D \text {, range, } \\
\text { n) }\end{array}$ & $\begin{array}{l}\text { Heidelberg } \\
\boldsymbol{M}(\boldsymbol{S} \boldsymbol{D}, \\
\text { range, } \boldsymbol{n})\end{array}$ \\
\hline $\begin{array}{l}\text { The training event is } \\
\text { useful for my classroom } \\
\text { practice. }\end{array}$ & $\begin{array}{l}4.00 \\
(1.23,2- \\
6,9)\end{array}$ & $\begin{array}{l}2.29 \\
(0.95,1-4,7)\end{array}$ & $\begin{array}{l}5.00 \\
(0.63,4-6,6)\end{array}$ & $\begin{array}{l}3.73 \\
(1.45,1-6,22)\end{array}$ & $\begin{array}{l}5.38 \\
(1.41,2-6,8)\end{array}$ \\
\hline $\begin{array}{l}\text { The training event's } \\
\text { objectives were clear. }\end{array}$ & $\begin{array}{l}5.11 \\
(1.36,2- \\
6,9)\end{array}$ & $\begin{array}{l}3.43 \\
(1.72,1-6,7)\end{array}$ & $\begin{array}{l}5.00 \\
(0.89,4-6,6)\end{array}$ & $\begin{array}{l}4.55 \\
(1.54,1-6,22)\end{array}$ & $\begin{array}{l}5.38 \\
(0.74,4-6,8)\end{array}$ \\
\hline $\begin{array}{l}\text { The training event's } \\
\text { objectives were met. }\end{array}$ & $\begin{array}{l}4.56 \\
(1.01,3- \\
6,9)\end{array}$ & $\begin{array}{l}3.14 \\
(0.90,2-4,7)\end{array}$ & $\begin{array}{l}5.50 \\
(0.55,5-6,6)\end{array}$ & $\begin{array}{l}4.36 \\
(1.26,2-6,22)\end{array}$ & $\begin{array}{l}5.29 \\
(1.11,3-6,7)\end{array}$ \\
\hline $\begin{array}{l}\text { The training event was } \\
\text { well-structured and easy } \\
\text { to follow. }\end{array}$ & $\begin{array}{l}5.44 \\
(0.53,5- \\
6,9)\end{array}$ & $\begin{array}{l}3.29 \\
(1.38,2-5,7)\end{array}$ & $\begin{array}{l}5.17 \\
(0.75,4-6,6)\end{array}$ & $\begin{array}{l}4.68 \\
(1.32,2-6,22)\end{array}$ & $\begin{array}{l}5.57 \\
(0.79,4-6,7)\end{array}$ \\
\hline $\begin{array}{l}\text { The trainer was well } \\
\text { prepared and } \\
\text { knowledgeable. }\end{array}$ & $\begin{array}{l}5.78 \\
(0.44,5- \\
6,9)\end{array}$ & $\begin{array}{l}3.33 \\
(1.37,2-5,6)\end{array}$ & $\begin{array}{l}5.67 \\
(0.52,5-6,6)\end{array}$ & $\begin{array}{l}5.05 \\
(1.36,2-6,21)\end{array}$ & $\begin{array}{l}5.57 \\
(0.79,4-6,7)\end{array}$ \\
\hline $\begin{array}{l}\text { I still have a lot of } \\
\text { unanswered questions. }\end{array}$ & $\begin{array}{l}3.56 \\
(1.24,2- \\
6,9)\end{array}$ & $\begin{array}{l}3.50 \\
(1.64,2-6,6)\end{array}$ & $\begin{array}{l}5.00 \\
(0.63,4-6,6)\end{array}$ & $\begin{array}{l}3.95 \\
(1.36,2-6,21)\end{array}$ & $\begin{array}{l}2.57 \\
(1.72,1-6,7)\end{array}$ \\
\hline $\begin{array}{l}\text { There was a good } \\
\text { balance between } \\
\text { presentation, hands-on } \\
\text { working with the } \\
\text { materials and } \\
\text { discussion. }\end{array}$ & $\begin{array}{l}5.44 \\
(0.53,5- \\
6,9)\end{array}$ & $\begin{array}{l}3.00 \\
(1.53,2-6,7)\end{array}$ & $\begin{array}{l}5.33 \\
(0.82,4-6,6)\end{array}$ & $\begin{array}{l}4.64 \\
(1.50,2-6,22)\end{array}$ & $\begin{array}{l}5.00 \\
(0.82,4-6,7)\end{array}$ \\
\hline MEAN score & $\begin{array}{l}4.83 \\
(0.43,4.43 \\
-5.86,9) \\
\end{array}$ & $\begin{array}{l}3.13 \\
(1.00,1.57- \\
4.57,7)\end{array}$ & $\begin{array}{l}4.81 \\
(0.41,4.29- \\
5.29,6) \\
\end{array}$ & $\begin{array}{l}4.28 \\
(1.02,1.57- \\
5.86,22) \\
\end{array}$ & $\begin{array}{l}5.21 \\
(0.71,3.71- \\
6,8)\end{array}$ \\
\hline $\begin{array}{l}\text { After the training event I } \\
\text { feel well prepared to do }\end{array}$ & 3.22 & $\begin{array}{l}2.43 \\
(0.98,1-4,7)\end{array}$ & $\begin{array}{l}4.83 \\
(1.17,3-6,6)\end{array}$ & $\begin{array}{l}3.41 \\
(1.56,1-6,22)\end{array}$ & $\begin{array}{l}4.43 \\
(1.27,3-6,7)\end{array}$ \\
\hline
\end{tabular}




\begin{tabular}{|c|c|c|c|c|c|}
\hline $\begin{array}{l}\text { a sample project with } \\
\text { my students. }\end{array}$ & $\begin{array}{l}(1.56,1- \\
5,9)\end{array}$ & & & & \\
\hline $\begin{array}{l}\text { After the training event I } \\
\text { feel well prepared to do } \\
\text { an own project with my } \\
\text { students. }\end{array}$ & $\begin{array}{l}2.67 \\
(1.32,1- \\
5,9)\end{array}$ & $\begin{array}{l}2.29 \\
(0.76,1-3,7)\end{array}$ & $\begin{array}{l}4.67 \\
(1.37,3-6,6)\end{array}$ & $\begin{array}{l}3.09 \\
(1.51,1-6,22)\end{array}$ & $\begin{array}{l}4.71 \\
(1.25,3-6,7)\end{array}$ \\
\hline MEAN score & $\begin{array}{l}2.94 \\
(1.40,1- \\
5,9)\end{array}$ & $\begin{array}{l}2.36 \\
(0.85,1- \\
3.5,7)\end{array}$ & $\begin{array}{l}4.75 \\
(1.25,3-6,6)\end{array}$ & $\begin{array}{l}3.25 \\
(1.51,1-6,22)\end{array}$ & $\begin{array}{l}4.57 \\
(1.24,3-6,7)\end{array}$ \\
\hline $\begin{array}{l}\text { How would you rate the } \\
\text { duration of the training } \\
\text { event? (too long, just } \\
\text { right, too short) }\end{array}$ & $\begin{array}{l}2.11 \\
(0.33,2- \\
3,9)\end{array}$ & $\begin{array}{l}2.00 \\
(0.89,1-3,6)\end{array}$ & $\begin{array}{l}2.17 \\
(0.41,2-3,6)\end{array}$ & $\begin{array}{l}2.10 \\
(0.54,1-3,21)\end{array}$ & $\begin{array}{l}2.14 \\
(0.38,2-3,7)\end{array}$ \\
\hline
\end{tabular}

Two MEAN scores were calculated, one focusing on the training event and the other on how prepared the participants now feel to use the project materials in their teaching. For that, the item "I still have a lot of unanswered questions" had to be reverse coded to match the direction of the other items. In Table 11, this item is shown in the original (not reversed) coding.

For the training event MEAN score, the seven items had a Cronbach's Alpha of $0.863(n=28)$. Overall, the average was 4.53 ( $S D=1.03$, range 1.57-6, $n=30)$. There were significant differences between participants in Switzerland and Germany ( $p=0.007$, Mann-Whitney) and among the Swiss language regions ( $p=0.003$, Kruskal-Wallis). Between Windisch and Lausanne there were statistically significant differences in results $(p=0.002)$, but not between Windisch and Locarno (Mann-Whitney).

For the teaching preparedness MEAN score, the two items had a Cronbach's Alpha of $0.962(n=29)$. Overall, the average was $3.57(S D=1.54$, range $1-6$, $n=29$ ). There were significant differences between participants in Switzerland and Germany ( $p=0.046$, t-test) and among the Swiss language regions $(p=0.006$, ANOVA). Between Windisch and Locarno there was a statistically significant difference in results $(p=0.025)$, but not between Windisch and Lausanne (t-test).

There was one comment from Lausanne: "The fact that the training was short was a decision taken on our side, the trainer did the most of it and brought the theoretical aspects very clearly. For a longer event, it would have been important to have some more thinking around didactical issues, such as: - take the educational context of the French-speaking part of Switzerland more into account (very little physical geography in our curriculum) - have some more discussions around the grade at which what can be implemented, and the time needed - show a wider range of possible implementations in class, discussing the difficulties and strength - underline in a clearer way how the fact of working online really brings something compared to working with printed images (is clearer in the case of bliF), as in quite a few schools computer access is still a big issue. On the overall, the course was very helpful to understand how teledection [remote sensing] worked, less useful on how we could use it in a realistic way in class in our context" [sic]. One participant from Windisch commented: "I still need more time" (translated). 


\section{Discussion and Conclusions}

The sample sizes were very small, and so it was impossible to look into the influence of background variables on the teachers' answers. For instance, does a greater familiarity with using satellite images influence a teacher's rating of the tasks and their suitability for different student age groups? Are there differences between male and female teachers? Small sample sizes also limit statistical power. Owing to these small sample sizes we cannot make broad generalizations about things such as observed differences between regions and countries. Based on the collected data, we cannot determine how many of the participants were certified teachers and how many were still in teacher training.

The YCHANGE curriculum was judged as a bit too ambitious by the participants. This study highlights that many participants judged themselves as not being particularly adept at dealing with satellite images before the training event. Although $44.4 \%$ of participants in Germany and $33.3 \%$ of participants in Switzerland reported that they could describe what satellite images or remote sensing are and read true color satellite images, they assessed that they could do no more than those rudimentary level 1 skills. In Germany, $11.1 \%$ of participants, and $18.2 \%$ of those in Switzerland, admitted that they could not even do those tasks, which puts them in possession of a skill set below level 1. This seems to be in line with studies, mostly from Germany, which report that satellite images are not universally used in class (Klein, 2007; Kollar, 2012; Alexandra Siegmund, 2011; Wabnitz, 2019) and Alexandra Siegmund's (2011) study which concludes that only $51 \%$ of teachers received some sort of introduction to working with satellite images. Yet, reading satellite images is a mandatory part of curricula such as the 'Curriculum 21', which teachers for Grades 7-9 in the Germanspeaking area of Switzerland have to teach (EDK, 2016). Consequently, teacher educators should ensure that their students get an introduction to working with satellite images. They cannot assume that their students have any remote sensing skills - even one as basic as reading true color satellite images.

The training event duration was rather short, ranging from two hours (Lausanne) to four hours (Heidelberg). Yet, overall, participants improved in their self-reported satellite image competence significantly in both Germany and in Switzerland. Even short training events can make a difference.

Despite judging the information provided in our project on preparing and administering student projects largely as sufficient, there were no student projects actually uploaded to our web platform. This could mean, for example, that:

- Participants prefer to use and possibly only adapt pre-fabricated worksheets. Sample projects were judged fairly favorably by the participants, except in Lausanne. Excluding Lausanne, participants felt rather well prepared, on average, $(M>3)$ to do sample projects with their students.

- Participants need more training and resources. On average, participants in Windisch and Lausanne did not feel well-prepared to do projects with their students $(\mathrm{M}<3)$.

- Project-based learning did not conform to the participants' preferred teaching styles. 
- Participants did projects with their students, but did not feel like sharing them on the web or did not want to take the time to do so.

More research is needed about how teachers can be better supported in teaching remote sensing.

Based on German studies (Dannwolf et al., 2020; Ditter \& Siegmund, 2016; Gehring, 2016) and the experiences of the Heidelberg team, the web application BLIF seemed promising. Overall, the YCHANGE study showed that BLIF was regarded, on average, rather positively by participants $(M>3)$ except in Lausanne. However, many evaluations of individual items on our questionnaire related to BLIF and the BLIF MEAN score were significantly lower in Switzerland than in Germany. Additionally, some comments also skewed in the same direction. This corroborated the Swiss team's informal observations.

The lower regard for BLIF in Switzerland is not the only significant difference between participants in Germany and Switzerland or among the Swiss language regions. Different factors could have contributed to these differences, such as:

- The small sample sizes increased the influence of each individual participant on the average scores.

- The sample composition was different from place to place. While the majority of the sample from Germany was female (88.9\%), only a minority of the Swiss sample was female (26.5\%). Studies of students have shown mixed results with regard to gender differences so far (Klein, 2007; Kollar, 2012; Alexandra Siegmund, 2011). It is plausible that there might be gender differences with regard to teachers, too.

- There were differences in the sample projects used. This applies not just to a somewhat different format of the materials used, but also to the topic. While the Heidelberg training used Costa Rica as a spatial example, the Switzerland training events used a Swiss example. A German study identified 'Germany', 'North America/USA', and 'The Alps' as the three most interesting topics for teachers (Hemmer \& Hemmer, 2017).

- Training duration varied. Lausanne participants, which were the most critical, had the shortest training duration. Even just slightly longer training events such as in Locarno and Windisch provided more time to use and learn the different remote sensing tools. Some comments in Lausanne suggest that not all parts of the intended training were addressed, or at least not sufficiently. That said, the participants on average judged all four training events - despite their different lengths and coverage of intended topics - as fairly right in length on average.

- All four training event locations have their own mandatory curricula. Thus, the perceived fit of the materials to the local curriculum might vary. That is suggested by one Lausanne participant who commented that there was "[...] very little physical geography in our curriculum [...]".

- Comments suggest that some participants in Lausanne had technical difficulties.

- There were three different instructors (Heidelberg, Locarno, and Windisch/Lausanne). Thus, there is a chance for instructor effects. Moreover, the training events were not the same, e.g., in terms of length, structure, etc., which makes direct comparisons difficult. 
- Different countries, and the various Swiss language regions, have somewhat different classroom practices and cultures. Thus, the materials and BLIF could have a better or worse fit to these local cultures and norms. This can be seen as innate factors that make adapting this project to a particular new location easier or harder.

Our YCHANGE project results suggest that promising approaches from one country cannot simply be transplanted to another - even neighboring - country, but more research is needed. Thus far, there seem to be few studies in geography education that compare the different Swiss language regions or different countries, even within the German speaking area (Germany/Liechtenstein/Switzerland/Austria). More such studies would be worthwhile.

This YCHANGE study, like others (e.g. Dannwolf et al., 2020; Gehring, 2016; Hodam et al., 2020; Lindner, Müller, Hodam, et al., 2019), only deals with one specific learning environment. We suggest that future studies compare different approaches to working with satellite images in education (e.g. the YCHANGE materials with worksheets vs. different learning platforms such as Geospektiv and FIS) in terms of their perceived usability as well as measured effectiveness, both from the teachers' and students' points of view.

\section{References}

Adaktylou, N. (2020). Remote Sensing as a Tool for Phenomenon-Based Teaching and Learning at the Elementary School Level: a Case Study for the Urban Heat Island Effect. International Journal of Educational Methodology, 6(3), 517-532. doi:10.12973/ijem.6.3.517

AKSA. (2013). Lehrpläne für das Grundlagenfach und Ergänzungsfach Geographie. Aarau: Alte Kantonsschule Aarau.

Amici, S., \& Tesar, M. (2020). Building Skills for the Future: Teaching High School Students to Utilize Remote Sensing of Wildfires. Remote Sensing, 12(21). doi:10.3390/rs12213635

Asimakopoulou, P., Nastos, P., \& Vassilakis, E. (2019). Using Copernicus EO data and services in compulsory education. Retrieved from http://users.uoa.gr/ evasilak/pages /pdfs/103\%20EGU_POSTER_v3.pdf

Avci, O., Ferraro, F., Fischbach, M., Giger, N., Gilgen, T., Sahdeva, P., Schulman, K. (2021). Wie sollten Forschungsergebnisse kommuniziert werden, so dass sie Lehrpersonen wirklich etwas bringen?Das Beispiel Klimawandel. Ein Studierendenprojekt im Rahmen des Moduls „Spezifische Aspekte geografiedidaktischer Forschung" im HS 2020. Retrieved from http://www. gesellschaftswissenschaften-phfhnw.ch/studierende-forschen-im-hs2020/

Billo, B., Meier, S., Oswald, A., von Lewinski, A., Wäschle, C., Zaugg, S., \& Viehrig, K. (2019). Kommen fachdidaktische Forschungsergebnisse in der Praxis an? Ein Studierendenprojekt im Rahmen des Moduls "Spezifische Aspekte geografiedidaktischer Forschung". Retrieved from http://www.gesellschaftswissenschaften-phfhnw.ch/studierende-forschenergebnisse-des-fachdidaktischen-studierendenprojekts-aus-dem-hs-2018/

Birch, J. (2012). Worldwide prevalence of red-green color deficiency. Abstract. Retrieved from https://pubmed.ncbi.nlm.nih.gov/22472762/ 
CD Geneve. (2016). Plan d'études. Geneva: Collège de Genève.

Cheung, Y., Pang, M., Lin, H., \& Lee, C. K. J. (2011). Enable Spatial Thinking Using GIS and Satellite Remote Sensing - A Teacher-Friendly Approach. Procedia - Social and Behavioral Sciences, 21, 130-138.

CIIP. (2008). Conférence intercantonale de l'instruction publique de la Suisse romande et du Tessin. Plan d'études romand. Neuchâtel CIIP.

Cortina, J. M. (1993). What Is Coefficient Alpha? An Examination of Theory and Applications.

Dannwolf, L., Matusch, T., Keller, J., Redlich, R., \& Siegmund, A. (2020). Bringing Earth Observation to Classrooms-The Importance of Out-of-School Learning Places and E-Learning. Remote Sensing, 12(19). doi:10.3390/rs12193117

Ditter, R., \& Siegmund, A. (2016). Lernen mit digitalen Satellitenbildern - eine genderspezifische Analyse. GW-Unterricht, 1, 162-173. doi:10.1553/gwunterricht142/143s 162

Ditter, R., Haspel, M., Jahn, M., Kollar, I., Siegmund, A., Viehrig, K., . . Siegmund, A. (2015). Geospatial technologies in school - theoretical concept and practical implementation. International Journal of Data Mining, Modelling and Management. Special Issue: Future GIS: Riding the wave of a growing geospatial technology literate society, 7(1), 3-23.

Dziob, D., Krupiński, M., Woźniak, E., \& Gabryszewski, R. (2020). Interdisciplinary Teaching Using Satellite Images as a Way to Introduce Remote Sensing in Secondary School. Remote Sensing, 12(18). doi:10.3390/rs12182868

EDK. (1994). Rahmenlehrplan für die Maturitätsschulen vom 9. Juni 1994. Empfehlung an die Kantone gemäss Art. 3 des Schulkonkordats vom 29. Oktober 1970. Mit Handreichungen zur Umsetzung. Berne: Sekretariat EDK.

EDK. (2016). Lehrplan 21. Räume, Zeiten, Gesellschaften (mit Geografie, Geschichte). Retrieved from http://v-ef.lehrplan.ch/

EDM Lausanne. (2016). Plan d'études et liste des examens Département de la formation, de la jeunesse et de la culture, Canton du Vaud. Lausanne: Ecole de maturité Lausanne.

Educause. (2012). 7 Things you should know about ... Educational Design Research. Retrieved from https://library.educause.edu/ /media/files/library/2012/8 /eli7087pdf.pdf

FG Bäumlihof. (2014). Lehrplan Gymnasium Bäumlihof, Übergangszeit 2014 -2021, Erziehungsdepartement des Kantons Basel-Stadt, Mittelschulen und Berufsbildung. Basel: Fachschaften Gymnasium Bäumlihof.

Gehring, T. S. (2016). Einsatz von Design Based Research in der Fernerkundungsdidaktik. (Master thesis, Heidelberg University of Education).

Gliem, J. A., \& Gliem, R. R. (2003). Calculating, Interpreting, and Reporting Cronbach's Alpha Reliability Coefficient for Likert-Type Scales. Retrieved from https://scholarworks.iupui.edu/bitstream/handle/1805/344/Gliem+\&+Gliem.pdf?se quence $=1$

Guo, Y. M., Klein, B. D., \& Ro, Y. K. (2019). On the effects of student interest, selfefficacy, and perceptions of the instructor on flow, satisfaction, and learning outcomes. Studies in Higher Education, 45(7), 1413-1430. doi:10.1080/03075079.2019.1593348 
Hemmer, I., \& Hemmer, M. (2010). Interesse von Schülerinnen und Schülern an einzelnen Themen, Regionen und Arbeitsweisen des Geographieunterrichts - ein Vergleich zweier empirischer Studien aus den Jahren 1995 und 2005. In I. Hemmer \& M. Hemmer (Eds.), Schülerinteresse an Themen, Regionen und Arbeitsweisen des Geographieunterrichts. Ergebnisse der empirischen Forschung und deren Konsequenzen für die Unterrichtspraxis (pp. 65-145).

Hemmer, I., \& Hemmer, M. (2017). Teachers' Interests in Geography Topics and Regions - How they Differ from Students' Interests? Empirical Findings. RIGEO, $7(1), 9-23$.

Hodam, H., Rienow, A., \& Jürgens, C. (2020). Bringing Earth Observation to Schools with Digital Integrated Learning Environments. Remote Sensing, 12(3). doi:10.3390/rs12030345

Jahn, M., Haspel, M., \& Siegmund, A. (2011). "Global change”: geography meets remote sensing in the context of the education for sustainable development. European Journal of Geography, 2(2), 21-34.

Jeřábek, J., Krčková, S., \& Hučínová, L. (2007). Rámcový vzdělávací program pro gymnázia, Výzkumný ústav pedagogický $v$ Praze. Retrieved from https://edumedia-

depot.gei.de/bitstream/handle/11163/1585/78285334X_2007_A.pdf?sequence=2

Kholoshyn, I., Bondarenko, O. V., Hanchuk, O. V., \& Varfolomyeyeva, I. M. (2020). Cloud technologies as a tool of creating Earth Remote Sensing educational resource. CEUR Workshop Proceedings 2643, 474-486.

Klein, U. (2007). Geomedienkompetenz. Untersuchung zur Akzeptanz und Anwendung von Geomedien im Geographieunterricht unter besonderer Berücksichtigung moderner Informations- und Kommunikationstechniken. (Dissertation). ChristianAlbrechts-Universität, Kiel.

Kollar, I. (2012). Die Satellitenbild-Lesekompetenz. Empirische Überprüfung eines theoriegeleiteten Kompetenzstrukturmodells für das "Lesen" von Satellitenbildern. (Dissertation). Heidelberg University of Education, Heidelberg.

KS Küsnacht. (2016). überarbeiteter Lehrplan Inkrafttreten im SJ 2016/16, Geographie Grundlagenfach und Ergänzungsfach. Küsnacht: Kantonsschule Küsnacht.

KS Limmattal. (2013/14). Lehrplan Grundlagen- und Ergänzungsfach Geographie. Urdorf: Kantonsschule Limmattal

KS Olten. (2014). Lehrplan Gymnasium Grundlagenfach Geographie. Olten: Kantonsschule Olten.

KS Zürcher Unterland. (2011/12). Lehrplan für die sechs und vierjährigen Lehrgänge des Gymnasiums. Bülach: Kantonsschule Zürcher Unterland.

Ld Lugano. (2008). Piano degli studi liceali Repubblica e Cantone Ticino Dipartimento dell'istruzione e della cultura. Lugano: Liceo di Lugano.

Lindner, C., Müller, C., Hodam, H., Jürgens, C., Ortwein, A., Schultz, J., . . Rienow, A. (2019). Expanding STEM Education in Secondary Schools: An Innovative Geography-Physics Course Focusing on Remote Sensing. GI_Forum, 1, 153-162. doi:10.1553/giscience2019_02_s153

Lindner, C., Müller, C., Ortwein, A., Hodam, H., Jürgens, C., Schultz, J., . . Rienow, A. (2019). Das Klassenzimmer im Weltraum - Anwendungen zur Erdbeobachtung zwischen Realität und Virtualität. Dreiländertagung der DGPF, der OVG und der SGPF in Wien, Österreich - Publikationen der DGPF, 28, 241-255. 
Lorenz, A., Roth, A., Priese, C., Peukert, E., Mertel, S., Bloß, S., \& Mehren, R. (2016). The interest of Bavarian primary school pupils in geographical topics and methods - selected results of an empirical survey. Education 3-13, 45(5), 543-557. doi:10.1080/03004279.2016.1140801

MKJSBW. (2018). Bildungsplan 2016 - Gymnasium Geographie. Retrieved from http://www.bildungsplaene-bw.de/,Lde/LS/BP2016BW/ALLG/GYM/GEO

NKSA. (2013). Fachlehrpläne Ergänzungsfach Geographie. Aarau: Neue Kantonsschule Aarau.

Picton, C., Nelson, K., \& Kahu, E. (2017). Student interest as a key driver of engagement for first year students. Student Success, 8(2), 55-66. doi:10.5204/ssj.v8i2.379

Plavén-Sigray, P., Matheson, G. J., Schiffler, B. C., \& Thompson, W. H. (2017). The readability of scientific texts is decreasing over time. elife, 6. doi:10.7554/eLife.27725

Plomp, T., \& Nieveen, N. (Eds.). (2010). An Introduction to Educational Design Research. Enschede: SLO.

Radl, N. (2018). Vermittlung von Klimawandel-und Klimaschutz-Inhalten in der Schule. (Master thesis). University of Vienna, Vienna, Austria.

Reuter, R. (2012). SEOS - Earsel's project on science education through earth observation for high schools / SEOS - Projeto EARSeL de educação científica para escolas de ensino médio, através de conhecimentos de observação da terra. Revista Ambiência, 8(Especial), 583-590. doi:10.5777/ambiencia.2012.04.01rc

Rienow, A., Hodam, H., Lindner, C., Ortwein, A., Schultz, J., \& Selg, F. (2018). Satelliteborne and iss-borne remote sensing in school lessons: lessons learned and new mediation ways. IEEE: IGARSS 2018, 6556-6559.

RÕK. (2011). Põhikooli riiklik õppekav. Retrieved from https://www.riigiteataja. ee/akt/114012011001

Siegmund, A. (2011). Satellitenbilder im Unterricht - eine Ländervergleichsstudie zur Ableitung fernerkundungsdidaktischer Grundsätze. (Dissertation). Heidelberg University of Education, Heidelberg. Retrieved from http://opus.bszbw.de/phhd/frontdoor.php?source_opus=7524\&la=de

Siegmund, A., \& Viehrig, K. (2012). Internationale Vernetzung. In J. B. Haversath (Ed.), Geographiedidaktik. Theorie - Themen - Forschung (pp. 56-63): Westermann.

Siegmund, A., Volz, D., \& Viehrig, K. (2007). GIS in the classroom - challenges and chances for geography teachers in Germany. Papers of the HERODOT working conference, Stockholm, Thematic Pillar 4: 'Employability'. Retrieved from http://www.herodot.net/conferences/stockholm/HERODOT-Stockholm2.html\#pres

Simpson, A. (2019). The evidential basis of "evidence-based education": an introduction to the special issue. Educational Research and Evaluation, 25(1-2), 1-6. doi:10.1080/13803611.2019.1617979

Solem, M., Stoltman, J., Lane, R., Bourke, T., Chang, C. H., \& Viehrig, K. (2018). An assessment framework and methodology for a Trends in International Geography Assessment Study (TIGAS). Geographical Education, 31, 7-15.

Steiniger, S., \& Bocher, E. (2009). An overview on current free and open source desktop GIS developments. International Journal of Geographical Information Science, 23(10), 1345-1370. doi:10.1080/13658810802634956 
Schulman, K. et al. (2021). Training teachers to use remote sensing: The YCHANGE project

Sullivan, M. (2018). Remote Sensing Technologies and Global Markets. Retrieved from https://www.bccresearch.com/market-research/instrumentation-andsensors/remote-sensing-technologies-and-global-markets-ias022f.html

Tallinna Nõmme Noortemaja Kosmoseklubi. (n.d.). Kosmoserobootika huviringi õppekava. Retrieved from https://nõmmehuvikool.ee/wp-content/uploads /2017/11/AK-Kosmoseklubi_kosmoserobootika.pdf

Tartu Observatory. (2018). Learning programmes. Retrieved from https://kylastuskeskus.to.ee/eng/program/learning_programmes

Viehrig, K. (2015). Exploring the effects of GIS use on students' achievement in geography. (Dissertation Dissertation). Heidelberg University of Education, Heidelberg. Retrieved from http://opus.ph-heidelberg.de/frontdoor/index/index /docld/71

Viehrig, K. (2017). Pre-service geography teachers' voices on the choice of spatial examples. Results from the first year of an educational design research study. $J$ Reading.https://www.researchgate.net/publication/317660938_Pre-service_ geography_teachers\%27_voices_on_the_choice_of_spatial_examples_Results_f rom_the_first_year_of_an_educational_design_research_study(corrected version). doi: $10.44 \overline{5} 8 / \overline{8} 57 \overline{9}-03$

Viehrig, K., Notter, N., Siegmund, A., Haemmerle, M., Fuchs, S., Naumann, S., . . . Lastovicka, J. (2018). YCHANGE - Fernerkundung in der Schul- und Lehrerbildung. GeoAgenda, 2018(1), 32-33.

Viehrig, K., Siegenthaler, D., Burri, S., Reinfried, S., Bednarz, S., Blankman, M., . . . Sprenger, S. (2019). Issues in improving geography and earth science teacher education: results of the \#IPGESTE 2016 conference. Journal of Geography in Higher Education, 43(3), 299-322. doi:10.1080/03098265.2019.1608920

Wabnitz, M. (2019). Blickbewegungen beim Lesen von Satellitenbildern - eine vergleichende Studie zur visuellen Wahrnehmung zwischen Schülern der Sekundarstufe I und Experten. (Dissertation, Heidelberg University of Education).

Wolf, N., Fuchsgruber, V., Viehrig, K., Naumann, S., \& Siegmund, A. (2015). Erdbeobachtung für Jugendliche - Entwicklung einer adaptiven, webbasierten Lernplattform für den Einsatz von Satellitenbildern im Geographieunterricht. Paper presented at the DGPF Tagungsband 24 / 2015. http://www.dgpf.de/src/tagung/jt2015/start.html

Wulder, M. A., Masek, J. G., Cohen, W. B., Loveland, T. R., \& Woodcock, C. E. (2012). Opening the archive: How free data has enabled the science and monitoring promise of Landsat. Remote Sensing of the Enviornment(122), 2-10.

\section{Appendix}

\section{The YCHANGE Remote Sensing Curriculum}

This remote sensing curriculum is a guideline for teachers, to help with selecting grade-appropriate learning activities for their students in remote sensing. It also includes thematic examples, but these are far from exhaustive. The teacher can freely decide which of the described approaches and competencies to pursue.

This curriculum is based on the national curricula of the YCHANGE project partners and their expertise in teaching and developing remote sensing materials as well as remote sensing education research (e.g., Kollar 2012). It is assumed that one is using standard desktop software (such as LeoWorks) or an online tool (such as BLIF). 
This curriculum describes a learning progression towards a professional use of remote sensing and digital satellite images in different job fields. It starts on a basic level, introducing rudimentary functionalities and methods. It then moves step-by-step to more advanced applications of remote sensing that ultimately provide access to a professional use of remote sensing in science, business, and public administration. Understanding remote sensing is also useful for contributing to public initiatives such as citizen science.

\section{Recommendations}

Ideally:

- By the end of Grade 6, students should reach level 1.

- By the end of Grade 10, students should reach level 4.

- By the end of Grade 12, students should reach level 5.

One can start on any level in any grade, depending on the skills and prior experience of the students. The target level should also be based on the students' individual competencies.

The teacher is free to decide which competence level to combine with which approach (e.g., I-1, II-2, I-3, II-5). We highly recommend that students create their own "student projects". After having worked with guided materials as an introduction, doing their own projects helps students in learning skills such as asking geographic questions, selecting appropriate methods, etc., which are demanded by many curricula.

\section{Level of Remote Sensing Approaches for Grade 5-12}

I Work with detailed step-by-step worksheets

II Work with general sample projects

III Create student-initiated projects (e.g., the students define a question and select appropriate tools and data)

\section{Level of Remote Sensing Competences for Grade 5-12}

These competencies define different levels of skills in analyzing satellite images in a progressive way. In some cases, the student can already move to the next level before having completed all parts of the previous level, e.g., a student needs to be able to read true color images before comparing two images, but a student can do classifications without having to know how to measure distance. The specific YCHANGE sample projects indicate requirements and target competencies.

The colors indicate:

The colors indicate:

- Competencies that could be reached with suitable printouts, Google Earth, or BLIF

- Competencies that could be reached with Google Earth or BLIF

- Competencies that could be reached with BLIF

Level Competencies: I can ...
Sample questions (not exhaustive)

1 A ... describe what a satellite images and remote sensing are.

B ... identify elements and structures on ("read") a true color satellite images.

2 A ... identify elements and structures on ("read") a false color satellite images.
Which objects can you see in a satellite image?

Which objects on the Earth's surface can be seen better in false color satellite images? 
B... evaluate the suitability of different image bands for a given question.

C ... measure distances and areas on satellite images.

A... compare satellite images (e.g., change detection).

4 A... understand the application of indices (e.g., NDVI) and read the resulting map.

B... understand applications and benefits of using remote sensing.

C... open a digital satellite image, apply automatic image enhancements, and understand the purpose of those enhancements.

$5 \quad$ A... classify satellite images (assisted manual classification or automatic classification) and read the resulting map.

B ... manually classify satellite images and select the appropriate band combination to do so.

C ... apply histogram manipulation and understand its purpose.

D ... understand limitations of remote sensing data and their impacts on satellite image analysis (e.g., resolution, cloud cover).
Which color band is best suited for emphasizing vegetated areas in satellite images?

What is the distance between $X$ and $Y$ ?

What are the differences between satellite image 1 and 2 ?

What is the main advantage of an index compared to color band combinations?

Why is remote sensing a valuable and powerful method?

Which preparatory steps would you perform to improve the visual appearance of satellite images?

What is the result of an automatic satellite image classification?

Which color band combinations support your manual classification?

What can be achieved via histogram manipulation in satellite images?

Which factors or situations can restrict the usefulness of satellite images?

\section{Beyond Grade 12}

The following competences can also be worked towards in BLIF, but they are suitable more for university students than secondary school students:

... read TerraSAR-X images

... use advanced methods such as scatterplots to select band combinations (e.g., for classification) or pan-sharpening for better spatial resolution.

There are also other competences that will be acquired in university, which are only available in advanced software (e.g., advanced corrections, creating composites).

\section{Further Reading to Extend General Skills in Remote Sensing}

- Canada Centre for Mapping and Earth Observation: Tutorial: Fundamentals of Remote Sensing. Available online: http://www.nrcan.gc.ca/node/9309 (last access: 2018-01-23).

- Schott, J.R. (2007): Remote Sensing - The Image Chain Approach. Oxford University Press.

\section{References}

BLIF - die webbasierte Fernerkundungssoftware für Schulen. BLIF - the web-based remote sensing software for school education. http://www.blif.de/ (last access: 2018-0112)

Kollar, I.(2012): Die Satellitenbild-Lesekompetenz. Empirische Überprüfung eines theoriegeleiteten Kompetenzstrukturmodells für das „Lesen“ von Satellitenbildern. The 
Satellite Image Reading Literacy. Empirical validation of a theoretical competence structure model of "reading" satellite images. Dissertation. http://nbnresolving.de/urn/resolver.pl?urn:nbn:de:bsz:he76-opus-75277 (last access: 2018-0112)

LEOWorks. Image Processing/Geographic Information System (GIS) for Educational Purposes. http://leoworks.terrasigna.com/ (last access: 2018-01-12)

\section{Biographical Statements}

Kathrin SCHULMAN (née Viehrig) currently works as a lecturer in Geography, Jewish Studies, and their Education at the FHNW School of Education in Switzerland. She has teacher certification in Baden-Württemberg, Germany, and in Switzerland; two master's degrees and a doctorate. Kathrin is interested in evidence-based education. She creates new research evidence (e.g., with regard to media as well as learner's and teachers' conceptions, beliefs, systemic thinking, and practices). She also makes research evidence more accessible to teachers and studies how this can be done more effectively (research communication). Her other interests include Judaism and agriculture.

Stephan FUCHS is a cultural geographer interested in the application of digital geomedia in science and education. His main foci are Geographic Information Systems and online applications of digital maps and imagery. Stephan Fuchs was trained at the University of Erlangen-Nuremberg and the University of Kansas and worked as a postdoctoral researcher at the University of Erlangen-Nuremberg, the University of Heidelberg and the Heidelberg University of Education. He has been involved in training students and teachers employing digital geo-media and contributed to the YCHANGE project as a coordinator.

Martin HÄMMERLE contributed within his former activities as a researcher and lecturer at the GIS-Station (Centre of Competence for Digital Geo-media at the Research Group for Earth Observation, Heidelberg University of Education) and as YCHANGE project coordinator. He was organizing and conducting lectures in which spatial aspects of the earth system were discussed based on the application of various GIS types. The courses covered topics relevant to school curricula, and the participants ranged from 4th grade students to professional teachers. Martin Hämmerle studied geography with foci on meteorology, climatology and 3D geodata analysis.

Thomas KISSER was a research associate at Heidelberg University of Education, Department of Geography from 2013 to 2017. He is a teacher at Gymnasium Bondenwald and teacher-trainer at the Landesinstitut für Lehrerbildung und Schulentwicklung Hamburg.

Josef LAŠTOVIČKA is a researcher in geoinformatics and remote sensing at Charles University in Prague, where he is also a lecturer on the basics of geoinformatics, remote sensing, GIS applications in social and physical geography, and 3D modeling for GIS. In his free time, he devotes himself to web creation, programming and 3D modeling. His dissertation deals with time series analysis of multispectral satellite images and processes of satellite data preprocessing for time observation of vegetation and vegetation changes caused by natural and anthropogenic calamities.

Nicole NOTTER is a certified teacher at a Swiss cantonal school. She is a former adjunct lecturer in geography and former research assistant at the FHNW School of Education in Switzerland. She studied geography with a focus on sustainable development, investigating social sustainability of different livelihood assets in Cuba. Currently, she is interested in integrating remote sensing data into geography classes for the visualization of environmental changes. 
PremysI STYCH is an associate professor of the Department of Applied Geoinformatics and Cartography at Charles University, Prague, where he is also a teacher of geoinformatics, remote sensing, and GIS applications. His fields of interests are land use/land cover change and time series analysis using multispectral satellite images and GIS.

Terje Väljataga is a senior researcher and lecturer at Tallinn University in the Center of Excellence in Educational Innovation. She holds a master's degree in geo-ecology, Tallinn University, Estonia; a master's degree in telematics applications in education and training, University of Twente, Netherlands, and a doctor of science in technology, Hypermedia Lab, Tampere University of Technology, Finland. Terje has teaching and coaching experience on the level of secondary, higher, and adult education. Since 2004, she has been involved in a variety of educational research projects.

Alexander SIEGMUND is a Professor of Physical Geography and Geo-Education, as well as chair holder of the "UNESCO Chair on Observation and Education of World Heritage and Biosphere Reserve" at the Heidelberg University of Education. Furthermore, he is an Honorary Professor at the University of Heidelberg. He fosters the use of modern geo-technologies in environmental and sustainability research and education for sustainable development (ESD). His research focuses on regional climate and climate change, geo-ecology, environmental monitoring \& modeling, applied remote sensing \& GIS, and environmental \& geo-education. He is founding member of the Heidelberg Center for the Environment (HCE) and member of the Baden-Württemberg Council on Sustainable Development. 